\title{
Calcium Regulates Vesicle Replenishment at the Cone Ribbon Synapse
}

\author{
Norbert Babai, ${ }^{1}$ Theodore M. Bartoletti, ${ }^{1,2}$ and Wallace B. Thoreson ${ }^{1,2}$ \\ Departments of ${ }^{1}$ Ophthalmology and Visual Sciences and ${ }^{2}$ Pharmacology and Experimental Neuroscience, University of Nebraska Medical Center, Omaha, \\ Nebraska 68198
}

Cones release glutamate-filled vesicles continuously in darkness, and changing illumination modulates this release. Because sustained release in darkness is governed by vesicle replenishment rates, we analyzed how cone membrane potential regulates replenishment. Synaptic release from cones was measured by recording postsynaptic currents in Ambystoma tigrinum horizontal or OFF bipolar cells evoked by depolarization of simultaneously voltage-clamped cones. We measured replenishment after attaining a steady state between vesicle release and replenishment using trains of test pulses. Increasing $\mathrm{Ca}^{2+}$ currents $\left(I_{\mathrm{Ca}}\right)$ by changing the test step from -30 to -10 $\mathrm{mV}$ increased replenishment. Lengthening $-30 \mathrm{mV}$ test pulses to match the $\mathrm{Ca}^{2+}$ influx during $25 \mathrm{~ms}$ test pulses to $-10 \mathrm{mV}$ produced similar replenishment rates. Reducing $\mathrm{Ca}^{2+}$ driving force by using test steps to $+30 \mathrm{mV}$ slowed replenishment. Using UV flashes to reverse inhibition of $I_{\mathrm{Ca}}$ by nifedipine accelerated replenishment. Increasing $\left[\mathrm{Ca}^{2+}\right]_{\mathrm{i}}$ by flash photolysis of caged $\mathrm{Ca}^{2+}$ also accelerated replenishment. Replenishment, but not the initial burst of release, was enhanced by using an intracellular $\mathrm{Ca}^{2+}$ buffer of $0.5 \mathrm{~mm} \mathrm{EGTA} \mathrm{rather}$ than $5 \mathrm{~mm}$ EGTA, and diminished by $1 \mathrm{~mm}$ BAPTA. This suggests that although release and replenishment exhibited similar $\mathrm{Ca}^{2+}$ dependencies, release sites are $<200 \mathrm{~nm}$ from Ca ${ }^{2+}$ channels but replenishment sites are $>200 \mathrm{~nm}$ away. Membrane potential thus regulates replenishment by controlling $\mathrm{Ca}^{2+}$ influx, principally by effects on replenishment mechanisms but also by altering releasable pool size. This in turn provides a mechanism for converting changes in light intensity into changes in sustained release at the cone ribbon synapse.

\section{Introduction}

Vertebrate cone photoreceptors are responsible for phototransduction and transmitting the resulting light responses to secondorder neurons. The relatively depolarized resting membrane potential of cones in darkness (approximately $-40 \mathrm{mV}$ ) promotes the opening of L-type $\mathrm{Ca}^{2+}$ channels. This elevates $\left[\mathrm{Ca}^{2+}\right]$ at the cone ribbon synapse to micromolar levels (Steele et al., 2005; Szikra and Krizaj, 2006; Choi et al., 2008; Jackman et al., 2009), sustaining the tonic release of glutamate. Synaptic vesicles must be continually replenished to maintain this tonic release for long periods in darkness. However, replenishment does not simply ensure the continued release of vesicles, but directly controls the rate of sustained release in darkness (Jackman et al., 2009). This results from the fact that synaptic release from photoreceptors is extremely sensitive to $\mathrm{Ca}^{2+}$ (Rieke and Schwartz, 1996; Thoreson et al., 2004) and thus intraterminal $\mathrm{Ca}^{2+}$ levels in darkness are sufficient to deplete the releasable pool of vesicles from the base of the synaptic ribbon (Jackman et al., 2009). The ratelimiting step in sustained release from cones in darkness is therefore not the rate at which vesicles can fuse, but the rate at which vesicles replenish the releasable pool (Jackman et al., 2009). Be-

\footnotetext{
Received June 7, 2010; revised Sept. 22, 2010; accepted Sept. 26, 2010.

This work was supported by Research to Prevent Blindness, National Institutes of Health Grant EY10542, and a University of Nebraska Medical Center graduate student fellowship (T.M.B.).

Correspondence should be addressed to Wallace B. Thoreson, Department of Ophthalmology and Visual Sciences, University of Nebraska Medical Center, 4050 Durham Research Center, Omaha, NE 68198-5840. E-mail: wbthores@ unmc.edu.

DOI:10.1523/JNEUROSCI.2891-10.2010

Copyright $\odot 2010$ the authors $\quad 0270-6474 / 10 / 3015866-12 \$ 15.00 / 0$
}

cause replenishment governs the rate of sustained release and sustained release is diminished by light-evoked hyperpolarization, replenishment rates in cones should be voltage dependent.

Voltage-dependent regulation of replenishment could result from at least three possible mechanisms: (1) voltage: similar to intrinsically voltage-dependent phosphatases (Murata et al., 2005), membrane potential changes might directly influence proteins involved in replenishment; (2) pool size: if each release site is replenished at a constant rate, then increasing the number of release sites can increase the rate of replenishment; and (3) calcium: the rate at which release-ready vesicles are replenished may be directly regulated by intracellular $\left[\mathrm{Ca}^{2+}\right]$. Using $\mathrm{Ca}^{2+}$ to regulate replenishment provides a mechanism for coupling replenishment rates to the activity of voltage-dependent $\mathrm{Ca}^{2+}$ channels. Furthermore, replenishment is known to be modulated by $\mathrm{Ca}^{2+}$ at other synapses, including Drosophila neuromuscular junction (Kuromi and Kidokoro, 2002, 2005), cerebellar basket cells (Sakaba, 2008), calyx of Held (Wang and Kaczmarek, 1998; Sakaba and Neher, 2001; Hosoi et al., 2007), Purkinje cells (Dittman and Regehr, 1998), hippocampal neurons (Stevens and Wesseling, 1998), inner hair cells (Johnson et al., 2008), and retinal bipolar cells (Mennerick and Matthews, 1996; Gomis et al., 1999; Singer and Diamond, 2006).

In this study, we recorded simultaneously from cones and postsynaptic neurons to determine factors regulating vesicle replenishment and sustained release at the cone ribbon synapse. We found that replenishment matched sustained release over a range of membrane potentials, supporting other evidence that replenishment is rate limiting for sustained release (Jackman et 
al., 2009). In addition, we found that replenishment exhibited a voltage dependence arising principally from direct regulation by $\left[\mathrm{Ca}^{2+}\right]_{\mathrm{i}}$, although it also involves changes in releasable pool size. $\mathrm{Ca}^{2+}$-dependent regulation of replenishment provides a mechanism for cones to convert changes in membrane potential into changes in sustained release and thereby encode changes in illumination at the cone ribbon synapse.

\section{Materials and Methods}

Retinal slice preparation. Aquatic tiger salamanders (Ambystoma tigrinum, Kons Scientific or Charles Sullivan) of both sexes $(18-25 \mathrm{~cm}$ in length) were handled according to protocols approved by the Institutional Animal Care and Use Committee at the University of Nebraska Medical Center. The salamander was decapitated with heavy shears, the cranium hemisected, and the spinal cord rapidly pithed. Animals were kept on a $12 \mathrm{~h}$ light/dark cycle and killed $1-2 \mathrm{~h}$ after the beginning of subjective night. After enucleation, the anterior segment of the eye, including the lens, was removed. The resulting eyecup was cut into thirds, and a section was placed vitreal side down on a piece of filter paper $(2 \times 5 \mathrm{~mm}$, type AAWP, $0.8 \mu \mathrm{m}$ pores, Millipore). After the retina adhered to the filter paper, the retina was isolated under chilled amphibian superfusate. The retina and filter paper were cut into $125 \mu \mathrm{m}$ slices using a razor blade (121-6, Ted Pella) tissue chopper (Stoelting). Retinal slices were rotated $90^{\circ}$ to view the retinal layers when placed under a water-immersion objective $(60 \times, 1.0 \mathrm{NA})$ on an upright fixed stage microscope (Nikon E600FN).

Electrophysiology. Cones were voltage clamped simultaneously with adjacent postsynaptic horizontal or OFF bipolar cells using a Multiclamp patch-clamp amplifier (Molecular Devices). Cones, horizontal cells, and OFF bipolar cells were identified by their morphology and response characteristics (Thoreson et al., 1997). Recording pipettes were positioned with Huxley-Wall micromanipulators (Sutter Instruments) and visualized through the eyepieces or using a video camera (Watec 502H) mounted on the microscope. Currents were low-pass filtered at $2 \mathrm{kHz}$ and acquired using a Digidata 1322 interface with pClamp 9.2 software (Molecular Devices). Photoreceptors were voltage clamped at $-70 \mathrm{mV}$, and horizontal and OFF bipolar cells were clamped at -50 and $-60 \mathrm{mV}$, respectively. Cells were identified by their morphology, light responses, and voltage-dependent currents (Cadetti et al., 2008). Acceptable access resistance was $<60 \mathrm{M} \Omega$. In the salamander retina slice preparation, OFF bipolar cells, cones, and many horizontal cells exhibit single-exponential charging curves, indicating compact electrotonic structures (Cadetti et al., 2005).

Patch pipettes were pulled on a PP-830 vertical puller (Narishige USA) from borosilicate glass pipettes $(1.2 \mathrm{~mm} \mathrm{OD}, 0.9 \mathrm{~mm}$ ID, with internal filament, World Precision Instruments) and had tips of $\sim 1-2 \mu \mathrm{m}$ OD with resistance values of $10-15 \mathrm{M} \Omega$. The presynaptic recording pipette was filled with a solution containing (in $\mathrm{mM}$ ) 40 Cs-glutamate, 50 Csgluconate, 9.4 tetraethylammonium chloride (TEACl), $3.5 \mathrm{NaCl}, 1$ $\mathrm{CaCl}_{2}, 1 \mathrm{MgCl}_{2}, 9.4 \mathrm{MgATP}, 0.5 \mathrm{GTP}, 5 \mathrm{EGTA}$, and 10 HEPES, pH 7.2. In some experiments, we replaced $5 \mathrm{~mm}$ EGTA with $0.5 \mathrm{~mm}$ EGTA or $1 \mathrm{~mm}$ 1,2-bis (o-aminophenoxy)ethane- $N, N, N^{\prime}, N^{\prime}$-tetraacetic acid (BAPTA). Postsynaptic pipettes were filled with a solution containing (in mM) 94 Cs-gluconate, 9.4 TEACl, 1.9 $\mathrm{MgCl}_{2}$, 9.4 MgATP, 0.5 GTP, 5 EGTA, and 32.9 HEPES, pH 7.2. The osmolarity of pipette solutions was adjusted, if necessary, to $\sim 240 \mathrm{mOsm}$.

Extracellular solutions were applied by a single-pass, gravity-feed perfusion system, which delivered superfusate to the slice chamber at a rate of $\sim 1 \mathrm{ml} / \mathrm{min}$. The normal amphibian superfusate contained the following (in mM): $111 \mathrm{NaCl}, 2.5 \mathrm{KCl}, 1.8 \mathrm{CaCl}_{2}, 0.5 \mathrm{MgCl}_{2}, 10 \mathrm{HEPES}$, and 5 glucose, $\mathrm{pH}$ 7.8. Use of HEPES as a $\mathrm{pH}$ buffer limited effects of proton feedback (DeVries, 2001; Hirasawa and Kaneko, 2003; Hosoi et al., 2005). The osmolarity was measured with a vapor pressure osmometer (Wescor) and adjusted, if necessary, to $\sim 245 \mathrm{mOsm}$. Solutions were bubbled continuously with $100 \% \mathrm{O}_{2}$.

To measure replenishment rates, we attained a steady state where the rate of replenishment balances the rate of release by applying a $7 \mathrm{~s}$ train of depolarizing pulses to the cone (Schneggenburger et al., 1999, 2002). We used test pulses of $\geq 25 \mathrm{~ms}$, which are sufficient to deplete the entire readily releasable pool (Rabl et al., 2005; Bartoletti et al., 2010). The interpulse intervals of 75 or $150 \mathrm{~ms}$ are shorter than the time constant for recovery from paired-pulse depression at cone synapses ( $\geq 250 \mathrm{~ms}$ ) (Rabl et al., 2006). To assess the amount of glutamate release, we measured the cumulative charge transfer by integrating EPSCs evoked during the pulse train. Baseline currents were subtracted before integration to remove leak currents and synaptic currents arising from neighboring photoreceptor cells. The rate of replenishment was calculated from the slope of a straight line fit to the cumulative charge transfer during the final $1-2 \mathrm{~s}$ of the train.

Fluorescence measurements and flash photolysis of caged $\mathrm{Ca}^{2+}$. Fluorescence measurements of $\left[\mathrm{Ca}^{2+}\right]_{i}$ were obtained from cones in retinal slices using a laser confocal scan head (PerkinElmer UltraView LCI) equipped with a cooled CCD camera (Orca ER) and mounted to a fixed stage upright microscope (Nikon E600 FN). The single frame duration was $57 \mathrm{~ms}$ and pixel values were binned $2 \times 2$. Excitation and emission were controlled by a Sutter Lambda 10-2 filter wheel and controller. Images were acquired and analyzed using UltraView Imaging Suite software.

DM-nitrophen (Kaplan and Ellis-Davies, 1988) was photolyzed by flashes of UV light derived from a Xenon arc flash lamp (JML-C2 Flash Lamp System, Rapp OptoElectronic) centered on the cone terminal and coupled through the epifluorescence port of the microscope. This flash lamp was also used for photolytic reversal of inhibition of the $\mathrm{Ca}^{2+}$ current $\left(I_{\mathrm{Ca}}\right)$ by nifedipine (Sanguinetti and Kass, 1984). Photolysis of DM-nitrophen allows rapid and uniform increases in $\left[\mathrm{Ca}^{2+}\right]_{\mathrm{i}}$ throughout the terminal (Kaplan and Ellis-Davies, 1988; Naraghi et al., 1998). The pipette solution for $\mathrm{Ca}^{2+}$ uncaging experiments consisted of the following (in $\mathrm{mM}$ ): $10 \mathrm{DM}$-nitrophen (Invitrogen), 0.5 Oregon-Green BAPTA-6F (OGB6-F; Invitrogen), $8 \mathrm{CaCl}_{2}, 2$ diaminopropanoltetraacetic acid (DPTA), 40 Cs-gluconate, 20 Cs-glutamate, 40 HEPES, 10 TEACl, $1 \mathrm{MgCl}_{2}$, and $0.5 \mathrm{GTP}$. Intraterminal $\mathrm{Ca}^{2+}$ was calculated using the following equation (Lev-Ram et al., 1992):

$$
\Delta\left[\mathrm{Ca}^{2+}\right]_{\mathrm{i}}=\frac{\left[\mathrm{Ca}^{2+}\right]_{\mathrm{rest}}+K_{\mathrm{d}}\left((\Delta F / F) /(\Delta F / F)_{\max }\right)}{1-(\Delta F / F) /(\Delta F / F)_{\max }} .
$$

$\Delta F / F$ represents the fractional change in OGB-6F fluorescence resulting from stimulation. $(\Delta F / F)_{\max }$ was determined from the maximal fluorescence change produced by application of $500 \mathrm{~ms}$ depolarizing steps to $-10 \mathrm{mV}$. We used the $K_{\mathrm{d}}$ of $3 \mu \mathrm{M}$ for OGB-6F provided by Invitrogen. The resting $\mathrm{Ca}^{2+}$ concentration $\left(\left[\mathrm{Ca}^{2+}\right]_{\text {rest }}\right.$ ) was determined ratiometrically from an aliquot of the pipette solution using $0.2 \mathrm{~mm}$ Fura-2 as described previously (Thoreson et al., 2004).

Unless otherwise stated, chemicals were obtained from Sigma-Aldrich. The criterion for statistical significance was chosen to be $p<0.05$ and evaluated using GraphPad Prism 4.0. Variability is reported as \pm SEM.

\section{Results}

\section{Comparison of replenishment and sustained release}

The rate of sustained release in darkness is governed by the rate of replenishment (Jackman et al., 2009). To test whether replenishment remains rate limiting for sustained release at more hyperpolarized membrane potentials, we examined the balance between rates of release and replenishment over a range of potentials spanning the normal physiological voltage range for cones. For these experiments, we applied lengthy depolarizing steps $(8 \mathrm{~s})$ to a range of test potentials from -65 to $-40 \mathrm{mV}$. At the end of the $8 \mathrm{~s}$ test step, we applied a probe step to $-10 \mathrm{mV}$ to stimulate release of all vesicles remaining in the readily releasable pool. As illustrated by the example in Figure $1 A$, application of a lengthy step from -70 to $-65 \mathrm{mV}$ evoked no detectable EPSC, but the probe step to $-10 \mathrm{mV}$ evoked a large EPSC of $210 \mathrm{pA}$. Increasing the amplitude of the $8 \mathrm{~s}$ test step in $5 \mathrm{mV}$ increments from -60 to $-40 \mathrm{mV}$ caused a progressive increase in the size of the initial EPSC and a decrease in the EPSC evoked by the probe step to -10 $\mathrm{mV}$. Thus, in this same cell, a test step to $-40 \mathrm{mV}$ evoked an EPSC of $38 \mathrm{pA}$ and the subsequent probe step to $-10 \mathrm{mV}$ evoked an EPSC of 119 pA (Fig. $1 B$ ). Although there was some rundown, the sum of these two responses (157 pA) is similar to the ampli- 
A
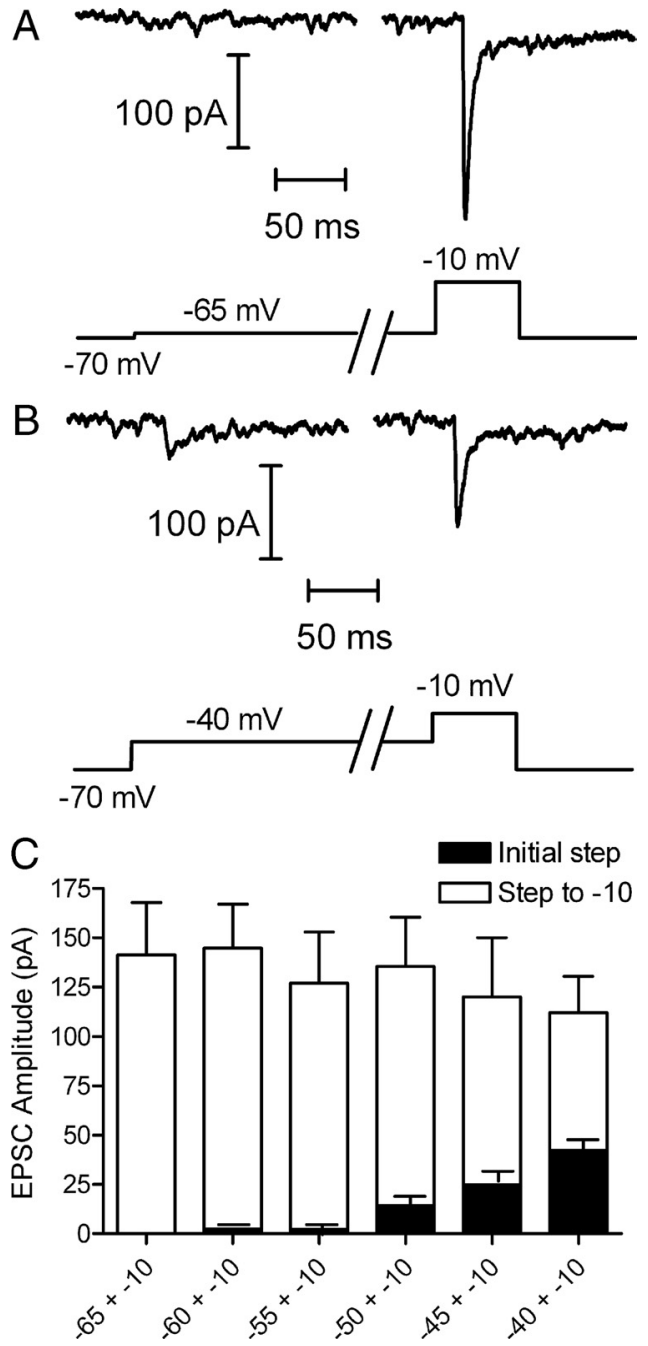

Figure 1. Replenishment rates match release rates during sustained depolarization in the physiological voltage range. $A$, Membrane current recorded from a voltage-clamped horizontal cell while applying a voltage step in the cone to -65 for $8 \mathrm{~s}$. This lengthy test step was followed by a probe step to $-10 \mathrm{mV}$ for $100 \mathrm{~ms}$ to stimulate release of the remainder of the readily releasable pool. $\boldsymbol{B}$, EPSC evoked in the same horizontal cell by an initial $8 \mathrm{~s}$ step to $-40 \mathrm{mV}$ and the subsequent probe step to $-10 \mathrm{mV}$. C, Stacked amplitudes of the initial $8 \mathrm{~s}$ test step (black bars, $n=13$ ) and subsequent probe step to $-10 \mathrm{mV}$ (white bars). The sum of both responses remained constant over the range of test steps from -65 to $-40 \mathrm{mV}$ (ANOVA, $p=0.90$ ), consistent with a balance between replenishment and release. The slight decrease in the summed response is due to response rundown during this extensive series of experiments.

tude of the EPSC evoked by the probe step from -65 to $-10 \mathrm{mV}$. The amplitude of the initial EPSC as a function of test step voltage is shown by the black bars in Figure $1 C$. The amplitude of the EPSC evoked by the probe step to $-10 \mathrm{mV}$ is shown by the white bars. If release rates exceed replenishment rates, then the releasable pool should be progressively depleted during the $8 \mathrm{~s}$ depolarization and the sum of the initial plus final EPSCs should diminish. If replenishment exceeds release, then the EPSC should recover during the steady depolarizing step and the sum of the two EPSCs should increase. Instead, the sum of both responses remained constant and equal to the size of the EPSC evoked by the probe step from -65 to $-10 \mathrm{mV}$ (Fig. 1C) (ANOVA, $p=$ $0.90)$. These data indicate that replenishment and release rates match one another, as expected if replenishment is rate limiting for sustained release.
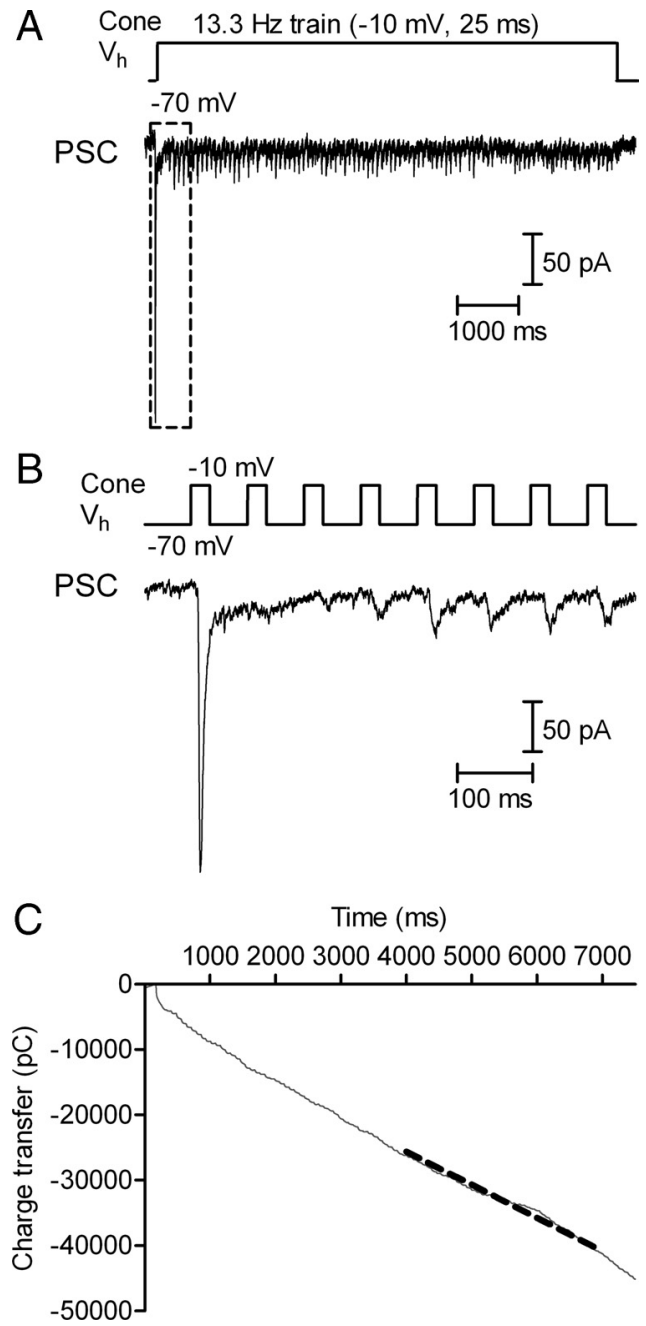

Figure 2. Measurement of replenishment rate at the cone synapse using pulse trains. $A, A 7 \mathrm{~s}$ pulse train $(13.3 \mathrm{~Hz}, 25 \mathrm{~ms}$ steps to $-10 \mathrm{mV})$ was applied to the cone while we simultaneously recorded the EPSC from an OFF bipolar cell. $V_{h}$, Membrane holding potential. $\boldsymbol{B}$, Responses to the first 8 test pulses (dashed square in $\boldsymbol{A}$ ). C, Cumulative EPSC charge transfer measured by integrating the entire EPSC trace. The replenishment rate was calculated from the linear slope of cumulative charge transfer during the final $2 \mathrm{~s}$ of the train. The dashed gray line shows the straight line fit to this region.

\section{Postsynaptic receptor saturation and desensitization with long-lasting stimuli}

To measure rates of replenishment at the cone synapse, we recorded simultaneously from a cone and postsynaptic OFF bipolar or horizontal cell. We applied a $7 \mathrm{~s}$ train of depolarizing pulses to the cone to empty the releasable pool and thereby attain a steady state where the rate of replenishment limits the rate of release (Schneggenburger et al., 1999, 2002). In the example in Figure 2, a train of $25 \mathrm{~ms}$ test steps from -70 to $-10 \mathrm{mV}$ was applied at a frequency of $13.3 \mathrm{~Hz}$. The EPSC evoked by the first pulse in the train, which reflects release of the entire readily releasable pool of $\sim 20$ vesicles per ribbon (Rabl et al., 2005; Bartoletti et al., 2010), averaged $110 \pm 6.4 \mathrm{pA}(n=50)$. Release diminished dramatically after the first EPSC with a slight recovery after $\sim 200 \mathrm{~ms}$ (Fig. 2 B). Maintained stimulation empties a reserve pool of $\sim 90$ additional vesicles with a time constant of $\sim 400 \mathrm{~ms}$ (Innocenti and Heidelberger, 2008; Bartoletti et al., 2010). To assess synaptic release during the train, we measured the cumulative charge transfer by integrating the series of EPSCs evoked by the entire train. We calculated the rate of replenishment from the slope of a straight 


\section{A Control}
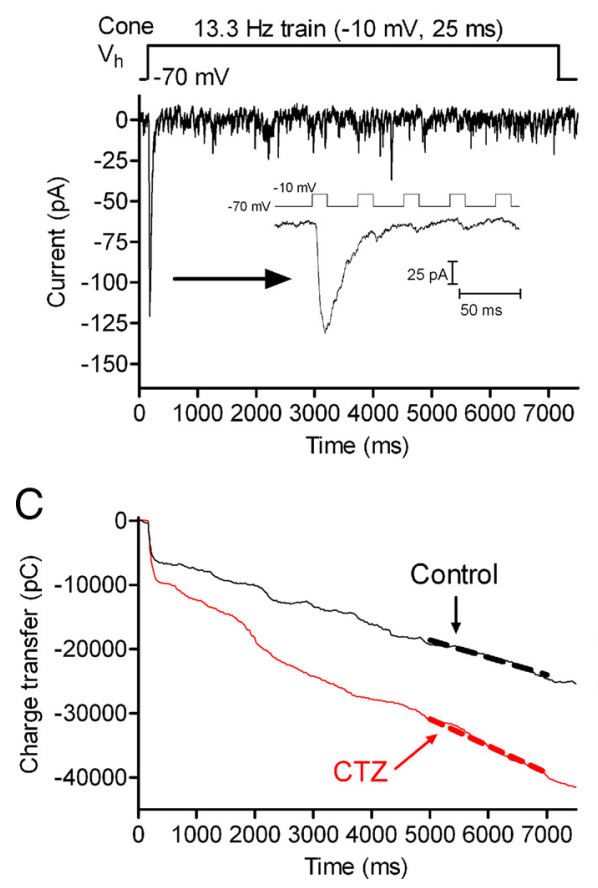

Figure 3. Cone synapses do not exhibit progressively increasing desensitization. $\boldsymbol{A}$, EPSC recorded from a voltage-clamped horizontal cell evoked by a pulse train $(13.3 \mathrm{~Hz}, 25 \mathrm{~ms}$ steps to $-10 \mathrm{mV})$ applied to a simultaneously voltage-clamped cone. Responses to the first five pulses are magnified in the inset. $\boldsymbol{B}$, Simultaneous recording from the same cone/horizontal cell pair after application of $100 \mu \mathrm{M}$ CTZ. Responses to the first five pulses are shown in the inset. C, EPSC charge transfer from the same horizontal cell measured in control conditions (black line) and after application of CTZ (red line). The linear fits to the final $2 \mathrm{~s}$ are shown by heavy dashed lines in both conditions. D, EPSC charge transfer in C divided by quantal amplitude in control ( $20.2 \pm 1.03$ $\mathrm{pC}, n=121$ events) and CTZ-treated conditions ( $31.3 \pm 1.56 \mathrm{pC}, n=100)$. After normalizing for differences in quantal size, the rate of quantal release during the final $2 \mathrm{~s}$ of the train did not differ greatly in control (black trace, 133 vesicles/s) and CTZ (red trace, 149 vesicles/s).

line fit to the cumulative charge transfer during the final $2 \mathrm{~s}$ of the train when replenishment balances release (Schneggenburger et al., 1999; Sakaba et al., 2002).

Although receptor saturation and desensitization may shape the kinetics of individual mEPSCs, mEPSCs exhibit sufficient spatiotemporal independence so that EPSCs evoked in horizontal or OFF bipolar cells by brief test steps applied to presynaptic cones can be constructed from a linear sum of individual mEPSCs (Cadetti et al., 2005, 2008). If continued release of glutamate during a pulse train caused a progressive increase in the amount of receptor saturation or desensitization, then one would expect to see a progressive decrease in the slope of the charge transfer relationship. This was not observed, suggesting that desensitization and saturation do not increase during the train.

One key piece of evidence for the ability of quanta to sum linearly during EPSCs was the finding that blocking glutamate receptor desensitization caused a comparable broadening of both quantal mEPSCs and EPSCs evoked by a brief depolarizing test step (Cadetti et al., 2005, 2008). To test whether EPSC charge transfer continues to provide an accurate measure of glutamate release with continued release during the pulse train, we tested effects of blocking desensitization with cyclothiazide (CTZ) (Patneau et al., 1993; Yamada and Tang, 1993). As expected (Kawai, 1999; Maple et al., 1999; Cadetti et al., 2005), CTZ (100 $\mu \mathrm{M})$ broadened OFF bipolar cell mEPSCs, increasing the quantal charge transfer by $38 \pm 9.6 \%(n=7$ cells $)$. If quanta sum linearly, then the increase in individual mEPSC charge transfer should cause the same broadening of the overall EPSC (Cadetti et al.,
2008). As illustrated in Figure 3, CTZ increased the initial EPSC (compare insets) as well as the slope of cumulative charge transfer during the final $2 \mathrm{~s}$ of the train (Fig. 3C). Normalizing the integrated EPSC in Figure $3 C$ by the single quantal charge measured in control and CTZtreated conditions yielded a very similar release profile in both conditions (Fig. $3 D)$. On average, the fast EPSC component increased by $36.1 \pm 13.4 \%(n=7$; control: $9663 \pm 1687$ pC; CTZ: 13,562 \pm $2656 \mathrm{pC}$ ) and the slope of cumulative charge transfer during the final $2 \mathrm{~s}$ of the train increased by $43.8 \pm 22.4 \%$ (control: $4.51 \pm 0.983 \mathrm{pC} / \mathrm{ms}$; CTZ: $5.65 \pm 1.02$ $\mathrm{pC} / \mathrm{ms})$. These values did not differ significantly from the increase in quantal charge transfer (ANOVA, $p=0.94$ ), suggesting that during protracted stimulation with a train of pulses, the postsynaptic effects of individual mEPSCs continue to sum linearly with one another and that charge transfer measurements provide a reliable measure of glutamate release throughout the train.

\section{Voltage dependence of replenishment}

To test whether replenishment rates vary with membrane voltage, we stimulated cones with a train of pulses to $-30 \mathrm{mV}$ (from $-70 \mathrm{mV}$ ) and then increased the pulse amplitude to $-10 \mathrm{mV}$ midway through the pulse train (Fig. $4 A$ ). Increasing the pulse amplitude to $-10 \mathrm{mV}$ stimulated a significantly ( $p=0.0003$, paired $t$ test $)$ faster replenishment rate (slope $=3.26 \pm 0.48 \mathrm{pC} / \mathrm{ms}, n=14$ ) than the rate measured with pulse trains to $-30 \mathrm{mV}$ (slope $=1.71 \pm 0.27$ $\mathrm{pC} / \mathrm{ms}$ ). Similar to the linear relationship between exocytosis and $I_{\mathrm{Ca}}$ at the photoreceptor synapse (Thoreson et al., 2004; Rabl et al., 2006), rates of replenishment varied in a nearly linear fashion with changes in cone $I_{\mathrm{Ca}}$ amplitude (slope $=0.84 \pm 0.062$ ) evoked by steps to different test potentials $(-40 \mathrm{mV}$ pulse train, $n=8 ;-30 \mathrm{mV}$ train, $n=14 ;-20 \mathrm{mV}$ train, $n=11 ;-10 \mathrm{mV}$ train, $n=22$ ).

We also examined replenishment using a longer interpulse interval of $150 \mathrm{~ms}(6.7 \mathrm{~Hz})$ (Fig. $4 \mathrm{~B})$. As found with an interval of $75 \mathrm{~ms}$, increasing test pulse amplitude from $-30 \mathrm{mV}$ to $-10 \mathrm{mV}$ stimulated a significantly faster replenishment rate (slope $=$ $7.32 \pm 2.35 \mathrm{pC} / \mathrm{ms}, n=8$ ) than the rate measured with the train to $-30 \mathrm{mV}$ (slope $=3.54 \pm 1.47 \mathrm{pC} / \mathrm{ms} ; p=0.02$, paired $t$ test $)$. Replenishment rates obtained with trains of test pulses to -10 $\mathrm{mV}$ did not differ significantly between the two interpulse intervals $(p=0.46, n=13)$.

The rate of replenishment could also be slowed by reducing test pulse amplitude from $-10 \mathrm{mV}$ to $-30 \mathrm{mV}$ (Fig. 4C). Using the $75 \mathrm{~ms}$ interpulse interval $(13.3 \mathrm{~Hz})$, replenishment rate declined significantly ( $p=0.0045$, paired $t$ test) from $5.13 \pm 1.19$ $(n=8)$ to $3.68 \pm 1.17 \mathrm{pC} / \mathrm{ms}$. With the $150 \mathrm{~ms}$ interpulse interval $(6.7 \mathrm{~Hz})$, replenishment rate declined significantly $(p=0.0018$, paired $t$ test) from $5.10 \pm 0.83(n=7)$ to $2.79 \pm 1.00 \mathrm{pC} / \mathrm{ms}$.

To test whether voltage-dependent changes in the rate of replenishment represent a direct effect of membrane voltage on 

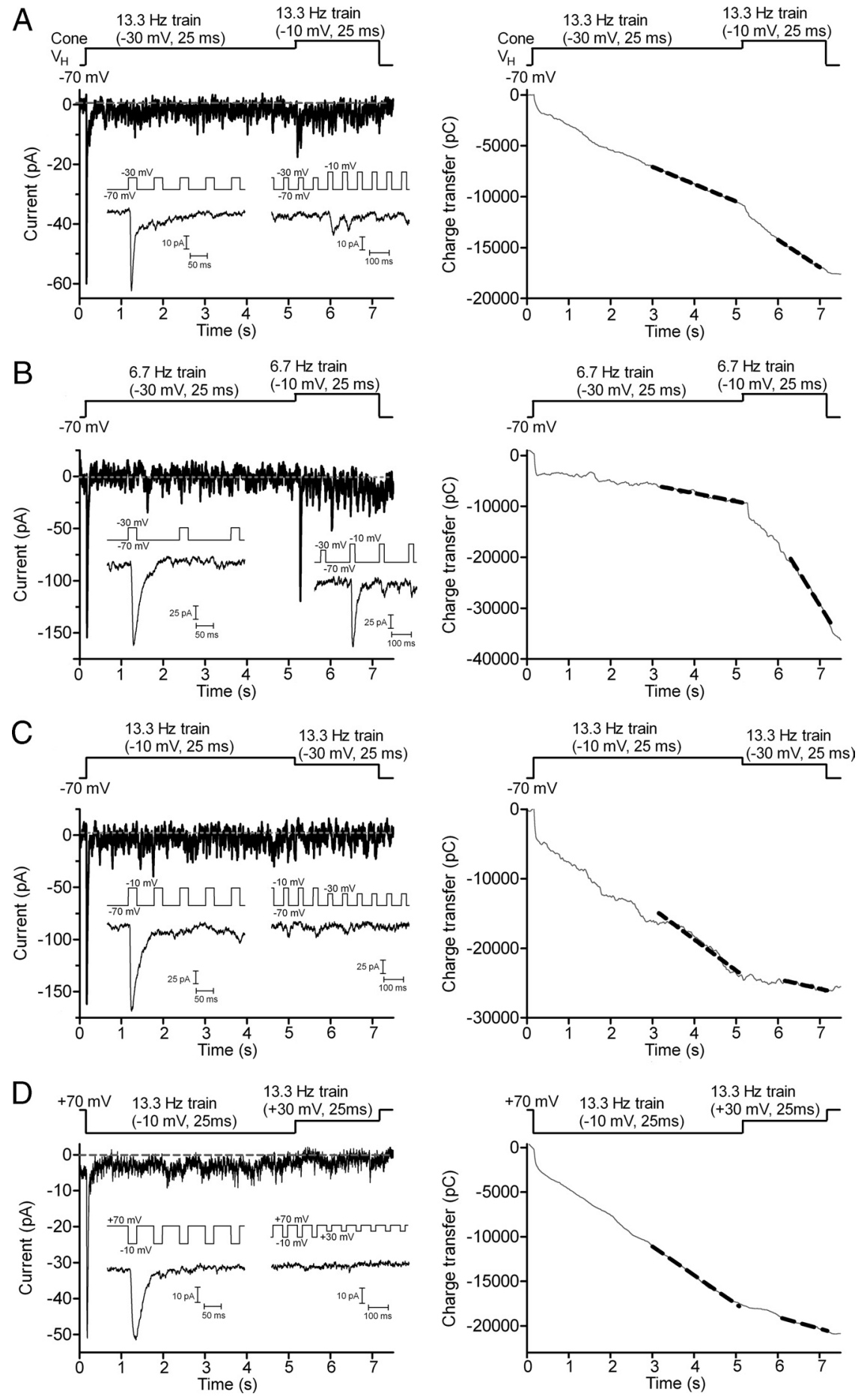

Figure 4. The rate of replenishment shows a voltage dependence arising from voltage-dependent changes in $\mathrm{Ca}^{2+}$ influx. $\boldsymbol{A}$, EPSC recorded from a voltage-clamped OFF bipolar cell evoked by a pulse train $(13.3 \mathrm{~Hz}, 25 \mathrm{~ms}$ steps from -70 to $-30 \mathrm{mV}$ ) applied to a simultaneously voltage-clamped cone. After $5 \mathrm{~s}$, the test step amplitude was increased to more strongly activate $I_{\mathrm{Ca}}$ and thereby increase $\mathrm{Ca}^{2+}$ influx $(13.3 \mathrm{~Hz}, 25 \mathrm{~ms}$ steps from -70 to $-10 \mathrm{mV})$. Insets show EPSCs evoked by the first five steps at the beginning of the pulse train and immediately after increasing test step amplitude. Right panel of $\boldsymbol{A}$, Cumulative charge transfer of the OFF bipolar EPSC shown at the left. Dashed line shows the straight line fits used to determine replenishment rates. The steeper slope indicates that replenishment rate increased after the test step was changed from $-30 \mathrm{mV}$ to $-10 \mathrm{mV}$. B, EPSC recorded from a different cone/OFF bipolar cell pair using a longer interpulse interval ( $150 \mathrm{~ms}$ ). After applying a $5 \mathrm{~s}$ train of pulses to $-30 \mathrm{mV}$ ( $6.7 \mathrm{~Hz}, 25 \mathrm{~ms}$ steps), the test step amplitude was increased to $-10 \mathrm{mV}$. Insets show EPSCs evoked at the beginning of the pulse train and immediately after increasing test step amplitude. Right panel of $\boldsymbol{B}$, Cumulative charge transfer of the OFF bipolar EPSC shown at the left. C, OFF bipolar cell EPSC evoked by a pulse train beginning with a train of steps to $-10 \mathrm{mV}(25 \mathrm{~ms}, 75 \mathrm{~ms}$ interpulse intervals, $13.3 \mathrm{~Hz}$ ) for $5 \mathrm{~s}$ followed by a $2 \mathrm{~s}$ train of steps to $-30 \mathrm{mV}$. Insets show EPS(s evoked at the beginning of the pulse train and immediately after changing test step amplitude. Right panel of $C$ : Cumulative charge transfer of the OFF bipolar EPSC in C shows a decline in replenishment when the test pulse amplitude was reduced from -10 to $-30 \mathrm{mV}$. The same cell pair proteins involved in replenishment $(\mathrm{Mu}-$ rata et al., 2005) or a voltage-dependent increase in $\mathrm{Ca}^{2+}$ influx through L-type $\mathrm{Ca}^{2+}$ channels (Wilkinson and Barnes, 1996), we tested a train with strongly depolarizing steps to $+30 \mathrm{mV}$. Because of the reduced driving force for $\mathrm{Ca}^{2+}$ entry at positive potentials, steps to $+30 \mathrm{mV}$ stimulated less $\mathrm{Ca}^{2+}$ influx than steps to $-10 \mathrm{mV}$. If replenishment is $\mathrm{Ca}^{2+}$ dependent, then the rate should decline with steps to $+30 \mathrm{mV}$. On the other hand, if replenishment is purely voltage dependent, then the rate should increase or remain the same with use of more strongly depolarizing test steps. We held the cell at $+70 \mathrm{mV}$, near the $\mathrm{Ca}^{2+}$ reversal potential. We applied a train of $25 \mathrm{~ms}$ pulses to -10 $\mathrm{mV}$ for the first $5 \mathrm{~s}$ and then switched to $+30 \mathrm{mV}$ pulses. As shown in Figure 4C, changing the pulse amplitude to +30 $\mathrm{mV}$ diminished replenishment rates by $64 \%$ (slope of -10 train: $2.36 \pm 0.47$ $\mathrm{pC} / \mathrm{ms},+30$ train: $0.85 \pm 0.12 \mathrm{pC} / \mathrm{ms}$, $n=6, p=0.0147)$, suggesting that the voltage dependence of replenishment is a result of voltage-dependent changes in $\mathrm{Ca}^{2+}$ influx.

\section{Lengthening stimulus pulse duration} accelerates replenishment

As an additional test of the hypothesis that replenishment is $\mathrm{Ca}^{2+}$ dependent, we lengthened $-30 \mathrm{mV}$ test steps to match the amount of $\mathrm{Ca}^{2+}$ influx during a $25 \mathrm{~ms}$ step to $-10 \mathrm{mV}$. On average, $65 \mathrm{~ms}$ steps to $-30 \mathrm{mV}$ stimulated the same amount of $\mathrm{Ca}^{2+}$ entry as $25 \mathrm{~ms}$ steps to $-10 \mathrm{mV}$ $(65.5 \pm 3.53 \mathrm{~ms}, n=9)$ (Fig. $5 A, B)$. Consistent with $\mathrm{Ca}^{2+}$ dependence of replenishment, use of a $13.3 \mathrm{~Hz}$ train consisting of $65 \mathrm{~ms}$ pulses to $-30 \mathrm{mV}$ produced nearly the same rate of replenishment $[3.07 \pm 0.66 \mathrm{pC} / \mathrm{ms} ; 154.3 \pm 33.3$ vesicles (v)/s/cone] as a $13.3 \mathrm{~Hz}$ train with $25 \mathrm{~ms}$ steps to $-10 \mathrm{mV}(3.20 \pm 0.67 \mathrm{pC} / \mathrm{ms}$, $160.9 \pm 33.7 \mathrm{v} / \mathrm{s} /$ cone, $p=0.122 ; n=10$ ) (Fig. $5 C, D$ ). Consistent with results of Figure 4 , a train of $25 \mathrm{~ms}$ pulses to -30 $\mathrm{mV}$ stimulated a significantly slower re-

$\leftarrow$

was used in B. D. EPSC recorded from another OFF bipolar cell during application of a pulse train $(13.3 \mathrm{~Hz}, 25 \mathrm{~ms}$ steps from +70 to $-10 \mathrm{mV}$ ) to a simultaneously voltage-clamped cone. After $5 \mathrm{~s}$, the test step amplitude was changed to reduce $\mathrm{Ca}^{2+}$ driving force and thereby reduce $\mathrm{Ca}^{2+}$ influx $(13.3 \mathrm{~Hz}, 25 \mathrm{~ms}$ steps from +70 to $+30 \mathrm{mV}$ ). Insets show EPS (s evoked at the beginning of the pulse train and immediately after changing test step amplitude. Right panel of $\boldsymbol{D}$, Cumulative charge transfer of the OFF bipolar EPSC in C shows a decline in replenishment when the test pulse amplitude was changed to $+30 \mathrm{mV}$. 
A
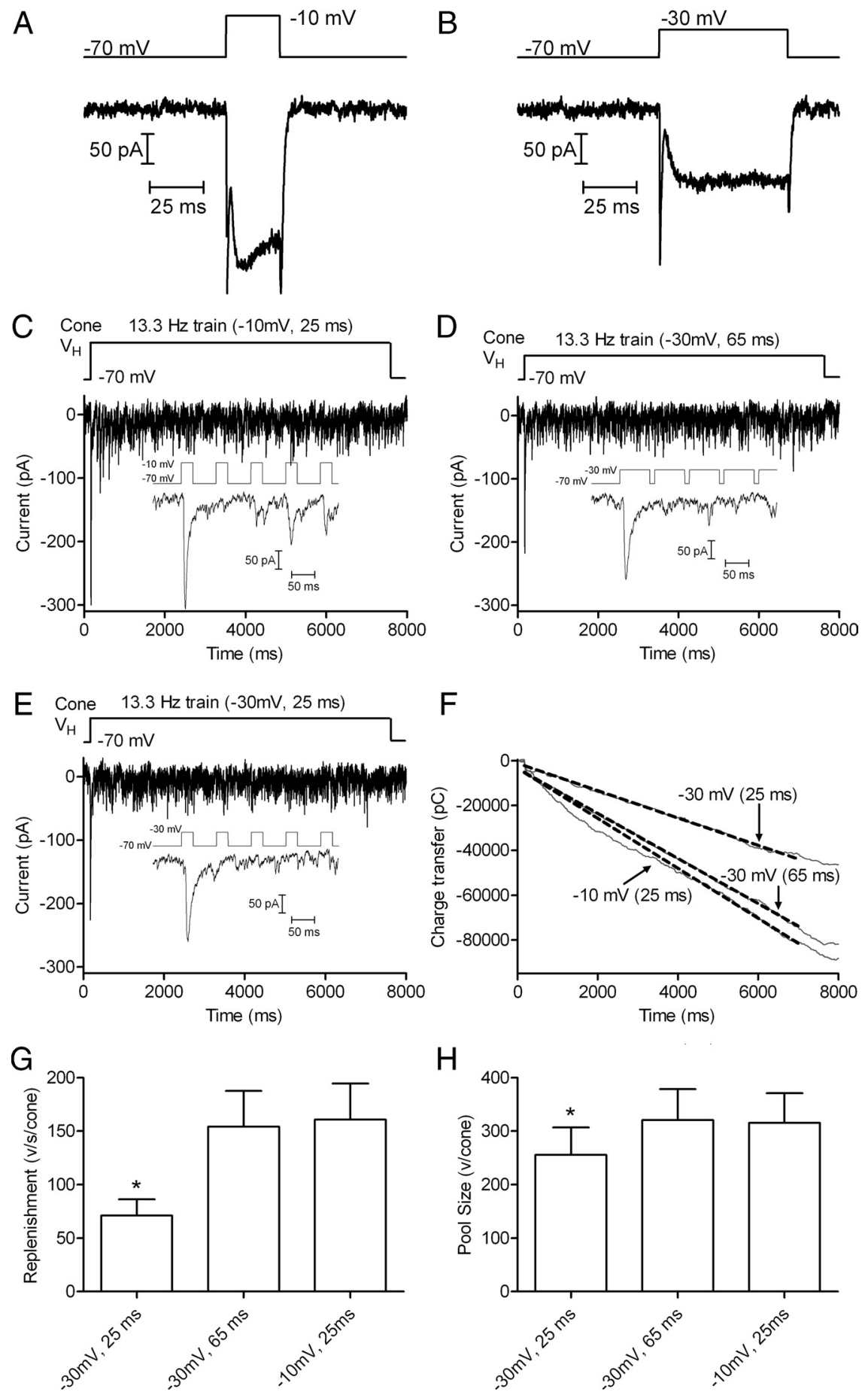

$\mathrm{H}$

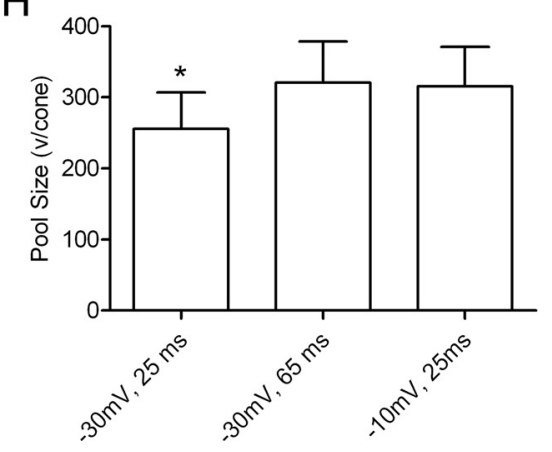

Figure 5. Matching calcium influx during steps to -30 and $-10 \mathrm{mV}$ yields matching replenishment rates. $\boldsymbol{A}, I_{\mathrm{Ca}}$ recorded from a cone in response to a $25 \mathrm{~ms}$ step from -70 to $-10 \mathrm{mV}$. Capacitative and leak currents were subtracted using a $\mathrm{P} / 8 \mathrm{protocol}$. $\boldsymbol{B}$, $I_{C a}$ recorded from the same cone in response to $65 \mathrm{~ms}$ step from -70 to $-30 \mathrm{mV}$. Although the amplitude differed, the charge transfer during $I_{\mathrm{Ca}}$ was similar with both stimuli: $6338 \mathrm{pC}$ during the $25 \mathrm{~ms}$ step to $-10 \mathrm{mV}$ and $6692 \mathrm{pC}$ during the $25 \mathrm{~ms}$ step to $-30 \mathrm{mV}$. C, EPSCs recorded from an OFF bipolar cell by application of $13.3 \mathrm{~Hz}$ train of pulses $(-70$ to $-30 \mathrm{mV}, 25 \mathrm{~ms})$ to a presynaptic cone. Inset shows the EPSC evoked by the first five pulses. D, EPSCs evoked in the same OFF bipolar cell by application of a $13.3 \mathrm{~Hz}$ train using stronger pulses $\left(-70\right.$ to $-10 \mathrm{mV}, 25 \mathrm{~ms}$ ) that stimulated greater $\mathrm{Ca}^{2+}$ influx into the presynaptic cone. $\boldsymbol{E}$, EPSCs evoked in the same OFF bipolar cell using a $13.3 \mathrm{~Hz}$ train of pulses to $-30 \mathrm{mV}$ that were lengthened to $65 \mathrm{~ms}$ to match the $\mathrm{Ca}^{2+}$ influx accompanying 25 ms pulses to $-10 \mathrm{mV}$. $\boldsymbol{F}$, Plot of cumulative charge transfer during the EPSC for the 3 different pulse trains from the same cell pair. Data points from 5 to $7 \mathrm{~s}$ were fit by linear regression to obtain the slope (replenishment rate) and $Y$-intercept (releasable pool size). G, Comparison of mean replenishment rates obtained with the three different pulse train protocols ( $n=10$ pairs). $\boldsymbol{H}$, Comparison of releasable pools measured with the three different pulse train protocols in the same cell pairs. plenishment rate $(1.42 \pm 0.30 \mathrm{pC} / \mathrm{ms}$; $71.1 \pm 15.1 \mathrm{v} / \mathrm{s} /$ cone; $p=0.0017$ ) (Fig. $5 E)$. This indicates that replenishment depends more on the amount of $\mathrm{Ca}^{2+}$ influx than on the pure voltage change in the membrane.

Extrapolating the straight line fit to the cumulative release function back to time 0 provides the size of the total vesicle pool that was initially available for release (Schneggenburger et al., 1999; Sakaba et al., 2002). We compared the size of the releasable pool by determining the $Y$-intercept of the straight line fit to the cumulative charge transfer functions obtained with different pulse train protocols. Charge transfer measurements were converted into quanta using an average amplitude of mEPSCs measured in 7 OFF bipolar cells of $19.9 \mathrm{pC} /$ vesicle $(n=325$ events). The vesicle pool emptied by a train of $25 \mathrm{~ms}$ steps to $-30 \mathrm{mV}$ was $5094 \pm 1010 \mathrm{pC}(256.0 \pm 50.74 \mathrm{v} /$ cone, $n=10), \sim 20 \%$ smaller than the pool emptied by a train of $25 \mathrm{~ms}$ steps to -10 $\mathrm{mV}(6281 \pm 1102 \mathrm{pC}, 315.6 \pm 55.4$ $\mathrm{v} /$ cone, $n=10 ; p=0.0001)$ or a train of 65 $\mathrm{ms}$ steps to $-30 \mathrm{mV}(6386 \pm 1144 \mathrm{pC}$, $320.9 \pm 57.5 \mathrm{v} /$ cone, $n=10, p=0.0012$ ) (Fig. 5). Scaled for the average amplitude of mEPSCs in OFF bipolar cells (6.7 \pm $0.14 \mathrm{pA}, n=325$ events), a single ribbon would be expected to contribute $54 \mathrm{pA}$ to the amplitude of the initial EPSC (Bartoletti et al., 2010). Thus, the amplitude of EPSCs in this sample of 10 cells (149.7 \pm $25.7 \mathrm{pA}$ ) suggests that each cone contacted each OFF bipolar cell at an average of 2.8 ribbons. This in turn implies that trains of $25 \mathrm{~ms}$ steps to $-10 \mathrm{mV}$ or $65 \mathrm{~ms}$ steps to $-30 \mathrm{mV}$ empty a releasable pool of $\sim 115$ vesicles per ribbon, close to the releasable pool size of $\sim 110$ vesicles per ribbon estimated previously (Bartoletti et al., 2010).

Every vesicle that is released at the synapse exits through the readily releasable pool. Therefore, expanding the size of the readily releasable pool would be expected to cause a linear increase in replenishment by increasing the number of available exits. Consistent with this, replenishment rates varied nearly linearly with the size of the readily releasable pool measured in different cell pairs ( slope $=0.82 \pm 0.18$, $\left.r^{2}=0.47, n=26\right)$. The reduction in replenishment rate observed with $25 \mathrm{~ms}$ steps to $-30 \mathrm{mV}$ can thus be partly explained by the availability of $20 \%$ fewer release sites. However, a 20\% reduction in pool size accounts for less than half of the $55 \%$ observed reduction in replenishment rate, suggesting that in addition to ex- 
A
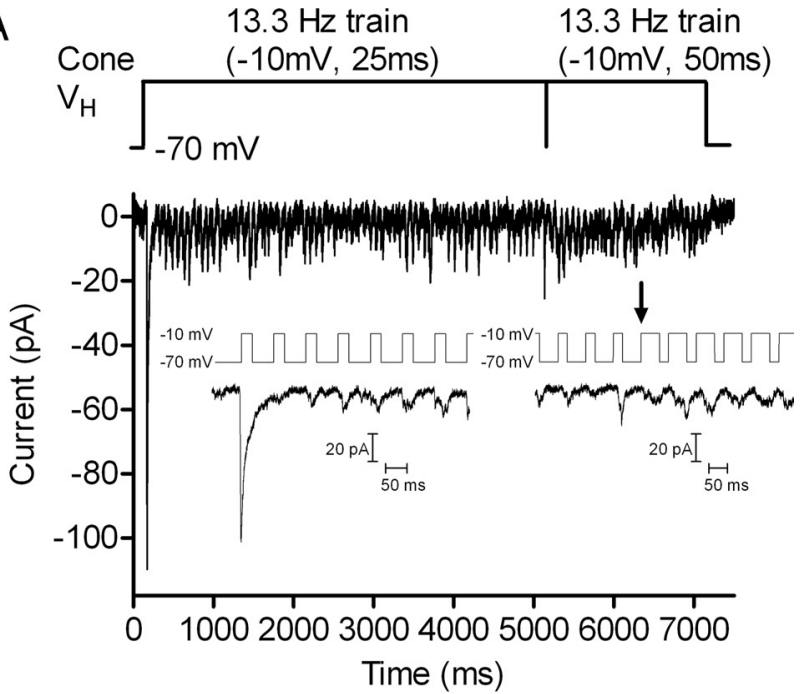

B
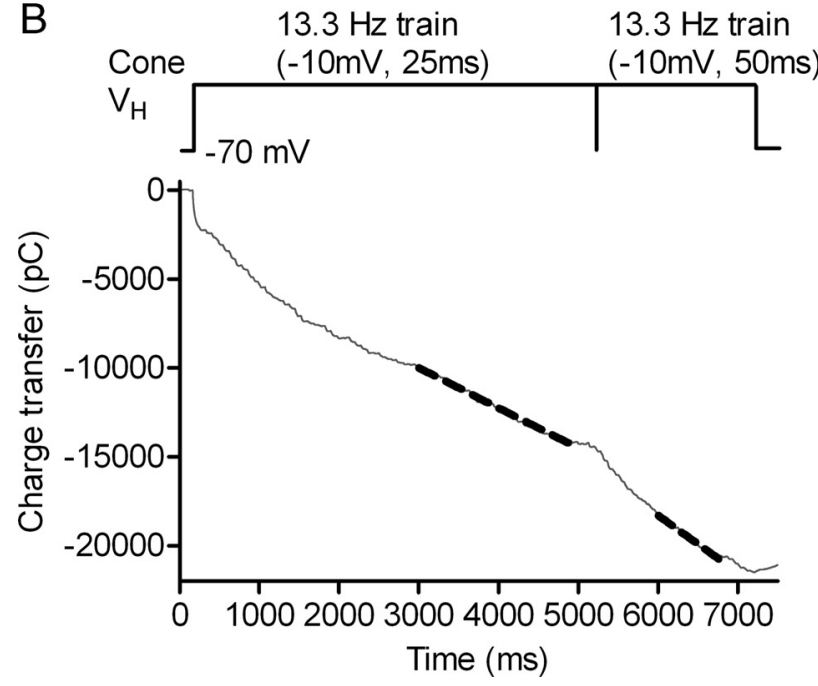

Figure 6. Lengthening a strong depolarizing pulse elevated replenishment rate without expanding the readily releasable pool. $A$, EPSCs recorded from a horizontal cell in response to a pulse train $(13.3 \mathrm{~Hz},-70$ to $-10 \mathrm{mV})$ applied to a simultaneously voltage-clamped cone. Five seconds into the trial, the pulse duration was lengthened from 25 to $50 \mathrm{~ms}$. Insets show the EPSCs evoked by the first five steps and when the test pulse was lengthened (arrow). Lengthening the test pulse did not evoke an appreciably larger EPSC, consistent with results from Bartoletti et al. (2010) that a $25 \mathrm{~ms}$ test pulse to $-10 \mathrm{mV}$ empties the readily releasable pool. $\boldsymbol{B}$, Cumulative release fit with straight lines at the end of each stimulus condition.

panding the readily releasable pool, $\mathrm{Ca}^{2+}$ speeds the recruitment of vesicles to this pool. Consistent with this, replenishment rate increased when $\mathrm{Ca}^{2+}$ influx was enhanced, but the size of the readily releasable pool did not expand. A train of $25 \mathrm{~ms}$ pulses to $-10 \mathrm{mV}$ completely empties the readily releasable pool (Bartoletti et al., 2010), and lengthening the pulse duration to $50 \mathrm{~ms}$ did not stimulate a larger EPSC, indicating that it did not evoke additional release (Fig. 6A). Although it did not expand the readily releasable pool, lengthening the pulse duration to $50 \mathrm{~ms}$ (256.6 \pm $40.4 \mathrm{v} / \mathrm{s} / \mathrm{cone}$ ) caused significantly more rapid replenishment than the $25 \mathrm{~ms}$ pulse train $(181.9 \pm 32.2 \mathrm{v} / \mathrm{s} /$ cone, $p<0.0001)$ (Fig. 6B).

Elevation of intraterminal calcium accelerates replenishment The results presented so far indicate that $\mathrm{Ca}^{2+}$ plays an important role in recruiting vesicles to the readily releasable pool. To test
A

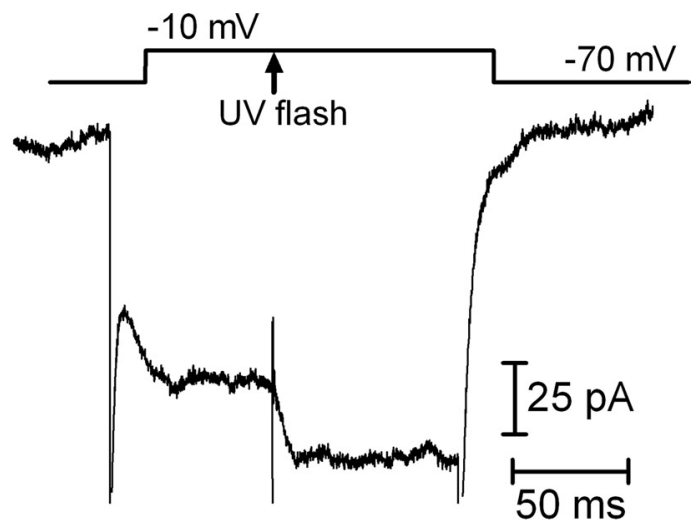

B
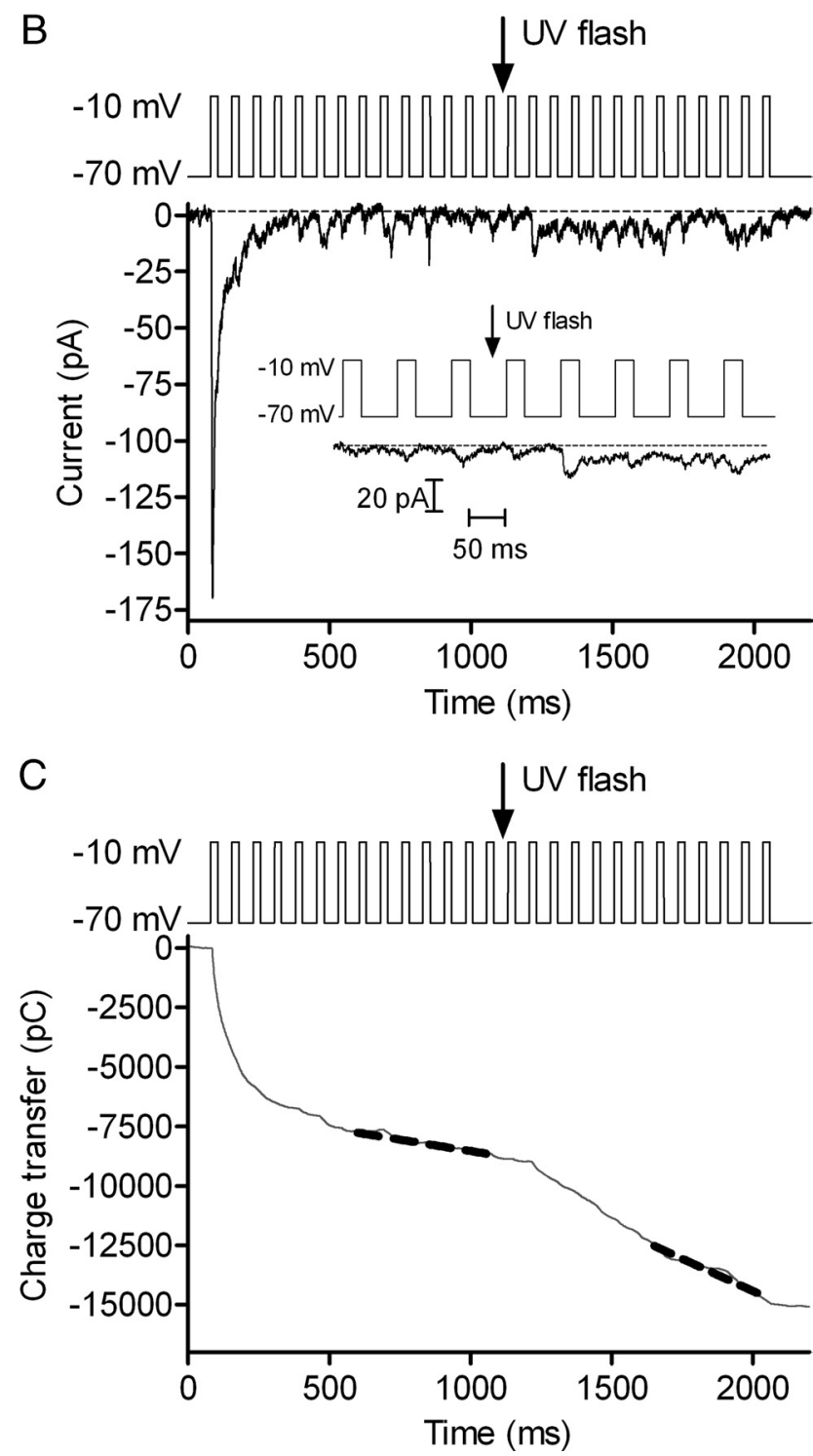

Figure 7. Abruptly unblocking L-type calcium channels increases replenishment rates. $A$, Cone $I_{C \mathrm{C}}$ recorded in the presence of $3 \mu \mathrm{m}$ nifedipine and evoked by a step from $-70 \mathrm{mV}$ to $-10 \mathrm{mV}$ ( $150 \mathrm{~ms})$. Capacitative and leak currents were subtracted using a P/8 protocol. A brief UV light flash applied in the middle of the step (arrow) abruptly increased $I_{C a}$ by photolytically unblocking the antagonistic effects of nifedipine (Sanguinetti and Kass, 1984). B, EPSCs recorded from an OFF bipolar cell in response to a pulsetrain $(13.3 \mathrm{~Hz},-70$ to $-10 \mathrm{mV})$ applied to a simultaneously voltage-clamped cone. Recording was obtained in the presence of $3 \mu \mathrm{m}$ nifedipine. AUV flash was applied in the middle of the pulse train to unblock nifedipine. Inset magnifies a section of the record to show EPSCS shortly before and after the flash. C, Cumulative charge transfer during the EPSC. Dashed gray line shows the straight line fits used to estimate the replenishment rates. 

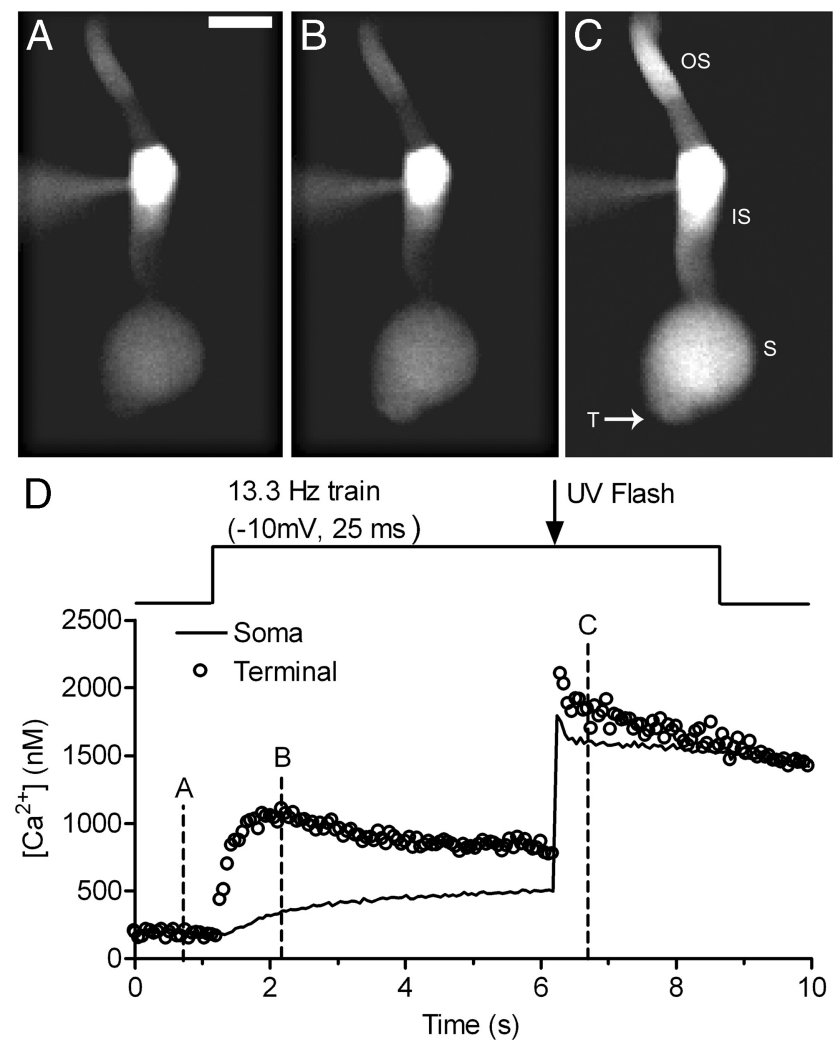

Figure 8. An example of calcium uncaging in a cone. $\boldsymbol{A}$, Single confocal section showing an image of a cone in the retinal slice loaded with DM-nitrophen (10 mM) and the $\mathrm{Ca}^{2+}$ indicator dye $0 \mathrm{~GB}-6 \mathrm{~F}(0.5 \mathrm{~mm})$ before stimulation (image was obtained at time point $A$ in the graph). Scale bar is $10 \mu \mathrm{m}$. $\boldsymbol{B}$, Applying a train of pulses ( $13.3 \mathrm{~Hz},-70 \mathrm{mV}$ to $-10 \mathrm{mV}, 25 \mathrm{~ms}$ ) increased fluorescence in the terminal and soma regions of the cone (time point $B$ in the graph). $C,\left[\mathrm{Ca}^{2+}\right]_{i}$ was rapidly elevated in both the soma and terminal by a flash of UV light (time point $($ in the graph). OS, Outer segment; IS, inner segment; $S$, soma; T, terminal. $\boldsymbol{D},\left[\mathrm{Ca}^{2+}\right]_{\mathrm{i}}$ change during the $-10 \mathrm{mV}$ train and the UV flash. Open circles show the $\mathrm{Ca}^{2+}$ level of the terminal and solid line shows the $\left[\mathrm{Ca}^{2+}\right]_{i}$ change measured in the center of the soma.

whether $\mathrm{Ca}^{2+}$ entry through L-type $\mathrm{Ca}^{2+}$ channels can accelerate replenishment, we abruptly increased $\mathrm{Ca}^{2+}$ influx into cones during a pulse train $(13.3 \mathrm{~Hz}$, steps to $-10 \mathrm{mV}$ for $25 \mathrm{~ms})$ by taking advantage of the fact that inhibitory effects of nifedipine on L-type $I_{\mathrm{Ca}}$ can be relieved by a bright UV light flash (Sanguinetti and Kass, 1984). Figure 7A shows that a brief UV flash enhanced cone $I_{\mathrm{Ca}}$ recorded in the presence of $3 \mu \mathrm{M}$ nifedipine by $30 \%$. This disinhibition persisted beyond the end of the train $(>1 \mathrm{~s})$. Increasing $\mathrm{Ca}^{2+}$ influx by unblocking nifedipine's inhibitory effects significantly accelerated the replenishment rate during a pulse train (Fig. 7) from $67.3 \pm 16.5$ to $199.5 \pm 25.1 \mathrm{v} / \mathrm{s} /$ cone $(p=0.0002, n=13)$. We did not observe a larger EPSC immediately after the UV flash (Fig. 7B, inset), indicating that the $\mathrm{Ca}^{2+}$-dependent increase in replenishment is not due to expansion of the readily releasable vesicle pool.

Focusing more directly on the role of $\mathrm{Ca}^{2+}$, we tested effects of elevating $\mathrm{Ca}^{2+}$ by flash photolysis of the caged $\mathrm{Ca}^{2+}$ compound, DM-nitrophen. Cones were dialyzed for $2-5$ min with DMnitrophen and $\mathrm{Ca}^{2+}$ indicator dye, OGB6-F, through the patch pipette. $\mathrm{Ca}^{2+}$ was uncaged in the middle of a pulse train $(13.3 \mathrm{~Hz}$, $25 \mathrm{~ms}$ steps to $-10 \mathrm{mV})$. Figure 8 shows an example of $\mathrm{Ca}^{2+}$ changes from a single confocal section of a cone during one such experiment. Before uncaging, the pulse train stimulated a $\mathrm{Ca}^{2+}$
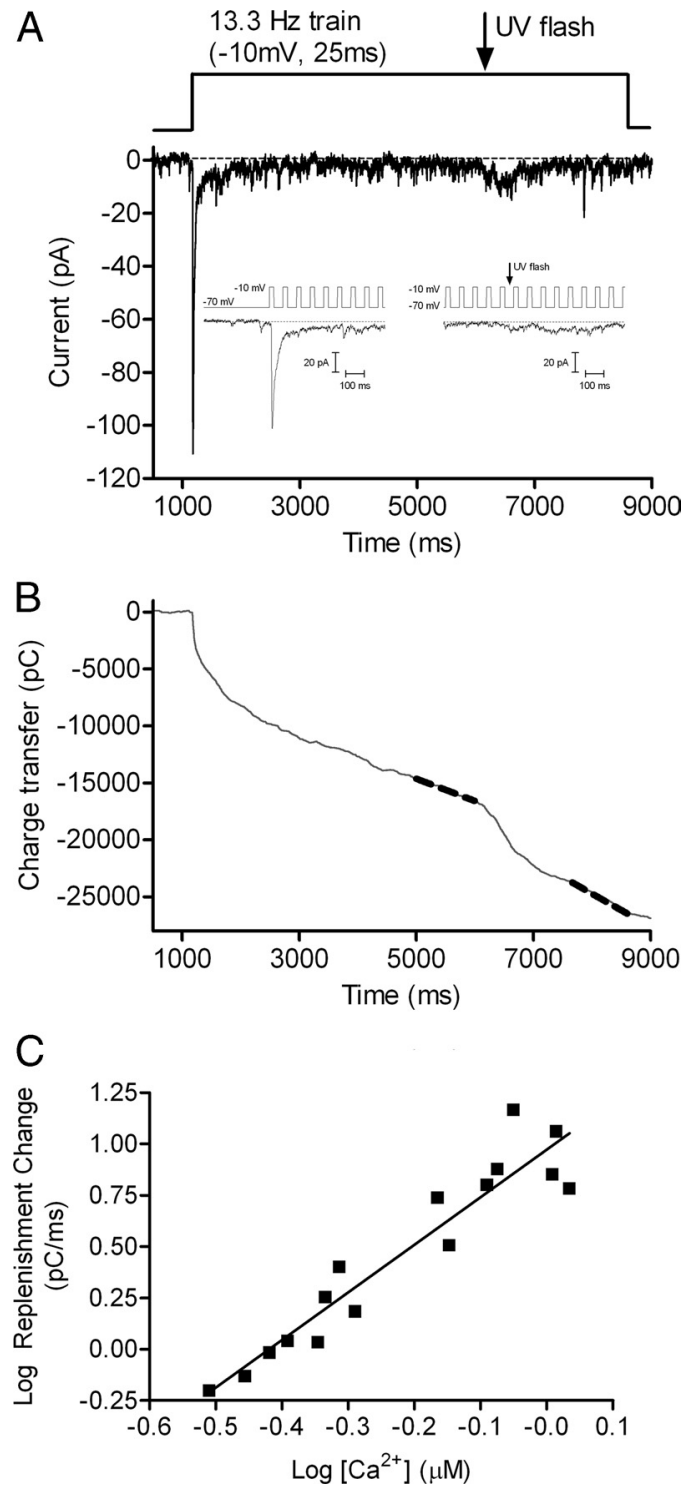

Figure 9. Intracellular calcium dependence of replenishment. $\boldsymbol{A}$, EPSCS recorded from an OFF bipolar cell in response to a pulse train $(13.3 \mathrm{~Hz},-70$ to $-10 \mathrm{mV})$ applied to a simultaneously voltage-clamped cone. $\mathrm{Ca}^{2+}$ was uncaged from DM-nitrophen by application of a UV light flash 5 sinto the trial. Insets magnify EPSCs at the start of the stimulus train and at the time of the UV flash. $\boldsymbol{B}$, Cumulative charge transfer during the pulse train. Dashed gray line shows the straight line fits used to determine the replenishment rate. $\boldsymbol{C}$, The relation between the change in replenishment rate observed after $\mathrm{Ca}^{2+}$ uncaging and postflash $\left[\mathrm{Ca}^{2+}\right]_{i}$ measured near the cone terminal. $\left[\mathrm{Ca}^{2+}\right]_{\mathrm{i}}$ was determined from 0GB-6F fluorescence changes using Equation 1. Data were plotted on $\log / \log$ axes. Solid line shows the straight line fit with a slope of $2.32 \pm 0.21$.

increase in the synaptic terminal region at the base of the cone. Consistent with the localization of $\mathrm{Ca}^{2+}$ channels to cone terminals (Nachman-Clewner et al., 1999; Xu and Slaughter, 2005), there was a smaller increase in the soma than in the terminal. Uncaging $\mathrm{Ca}^{2+}$ from DM-nitrophen with a short UV flash further increased $\left[\mathrm{Ca}^{2+}\right]_{\mathrm{i}}$ to similar levels in the terminal and soma (Fig. 8C). The slightly higher level attained in the terminal is likely due to the higher level present in the terminal before the flash. We acquired images of the cone every $60 \mathrm{~ms}$ and measured $\left[\mathrm{Ca}^{2+}\right]_{\mathrm{i}}$ as close as possible to the terminal. As shown in Figure 9, abruptly elevating $\left[\mathrm{Ca}^{2+}\right]_{\mathrm{i}}$ in a cone $5 \mathrm{~s}$ into the pulse train by photolytic uncaging of DM-nitrophen speeded replenishment from $125.2 \pm$ $31.6 \mathrm{v} / \mathrm{s} /$ cone to $312.2 \pm 79.64 \mathrm{v} / \mathrm{s} /$ cone $(p=0.0037)$. Figure $9 \mathrm{C}$ 
shows the increase in replenishment from multiple cells plotted as a function of $\left[\mathrm{Ca}^{2+}\right]_{\mathrm{i}}$. The replenishment rate increased when $\left[\mathrm{Ca}^{2+}\right]_{\mathrm{i}}$ was elevated above $\sim 300 \mathrm{nM}$, and this $\mathrm{Ca}^{2+}$-dependent increase showed a slope of 2.3 when plotted on $\log / \log$ axes (Fig. 9C). These properties are similar to $\mathrm{Ca}^{2+}$ dependence of exocytosis from cones, which exhibits a threshold of $\sim 400 \mathrm{~nm}$ and power law relationship of $\sim 2$ (Duncan et al., 2010).

\section{Location of $\mathrm{Ca}^{2+}$-dependent sites in replenishment}

Replenishment and release exhibit similar $\mathrm{Ca}^{2+}$ dependencies, but do both mechanisms involve the same sites? To address this question, we compared the locations of $\mathrm{Ca}^{2+}$-dependent sites involved in replenishment and release by using different $\mathrm{Ca}^{2+}$ buffers to limit the spread of $\mathrm{Ca}^{2+}$ from voltage-gated $\mathrm{Ca}^{2+}$ channels. We compared the effects on EPSC charge transfer of increasing the pulse amplitude from -30 $\mathrm{mV}(25 \mathrm{~ms}, 13.3 \mathrm{~Hz})$ to $-10 \mathrm{mV}(25 \mathrm{~ms}$, $13.3 \mathrm{~Hz}$ ) when using $1 \mathrm{~mm}$ BAPTA, $0.5 \mathrm{~mm}$ EGTA, or 5 mM EGTA in the cone patch pipette. Figure 10, $A$ and $B$, illustrates EPSCs obtained from different cell pairs using 1 mM BAPTA and 0.5 mM EGTA, respectively. Figure $10 \mathrm{C}$ shows the cumulative EPSC charge transfer during the pulse trains in these same two experiments. Increasing pulse strength from -30 to $-10 \mathrm{mV}$ stimulated a much larger increase in replenishment (steeper slope) when using $0.5 \mathrm{~mm}$ EGTA than with $5 \mathrm{~mm}$ BAPTA in the patch pipette (Fig. 10C). Figure $4 A$ showed EPSCs obtained with the same experimental protocol using 5 mM EGTA. A comparison of the slopes of the lines fit to cumulative EPSC charge transfer in all three buffer conditions shows that the increase in replenishment rate stimulated by increasing pulse strength from $-30 \mathrm{mV}$ to $-10 \mathrm{mV}$ diminished significantly as $\mathrm{Ca}^{2+}$ buffering was increased (Fig. 10D). Buffer space constants were estimated at $22 \mathrm{~nm}$ for $1 \mathrm{mmBAPTA}\left(k_{\mathrm{on}}=6 \times 10^{8} \mathrm{M}^{-1} \cdot \mathrm{s}^{-1}\right)$ (Tsien, 1980), $200 \mathrm{~nm}$ for $5 \mathrm{~mm}$ EGTA $\left(k_{\mathrm{on}}=1.5 \times 10^{6} \mathrm{M}^{-1} \cdot \mathrm{s}^{-1}\right)$ (Adler et al., 1991), and $632 \mathrm{~nm}$ for $0.5 \mathrm{~mm}$ EGTA (Roberts, 1993). The finding that replenishment rates differed in all three buffer conditions suggests that replenishment involves sites $>200 \mathrm{~nm}$ from $\mathrm{Ca}^{2+}$ channels clustered at the base of the ribbon. By contrast, the initial fast EPSC was not significantly diminished by changing the EGTA concentration from $0.5 \mathrm{~mm}$ $(n=10)$ to $5 \mathrm{~mm}(n=18, p=0.26)$ or use of $1 \mathrm{~mm} \mathrm{BAPTA}(0.5$ mM EGTA vs 1 mM BAPTA, $p=0.07 ; 5$ mM EGTA vs $1 \mathrm{~mm}$ BAPTA, $p=0.12, n=11$ ), suggesting that sites of exocytosis are $<200 \mathrm{~nm}$ from $\mathrm{Ca}^{2+}$ channels and perhaps as close as $20 \mathrm{~nm}$. Thus, although the $\mathrm{Ca}^{2+}$ dependencies are similar, $\mathrm{Ca}^{2+}$. dependent sites of replenishment involve locations that are distinct from fusion sites.

\section{Discussion}

Similar to other neurons, cone photoreceptors possess readily releasable, reserve, and resting pools of synaptic vesicles. The readily releasable pool consists of $\sim 20$ vesicles per ribbon, matching the number of vesicles contacting the plasma membrane at base of the ribbon (Bartoletti et al., 2010). With strong maintained stimulation, a second releasable pool of $\sim 90$ vesicles is depleted with a time constant of $\sim 400 \mathrm{~ms}$ (Innocenti and Heidelberger, 2008; Bartoletti et al., 2010). This reserve pool matches the number of vesicles tethered to the remainder of the ribbon. Consistent with previous results (Bartoletti et al., 2010), the present study yielded a total (readily releasable plus reserve) pool of $\sim 115$ vesicles per ribbon. After depleting the readily releasable and reserve pools, the cone synapse can maintain release indefinitely by accessing the resting pool. Our results support the hypothesis that sustained release evoked by maintained depolarization is limited by the rate of vesicle replenishment. We further show that the replenishment rate, and thus the rate of sustained release, exhibits a voltage dependence conferred largely by a $\mathrm{Ca}^{2+}$ dependence of replenishment.

The evidence for $\mathrm{Ca}^{2+}$ dependence of replenishment includes the following results: (1) matching the amount of $\mathrm{Ca}^{2+}$ influx during steps to different test voltages yielded similar replenishment rates, (2) reducing $\mathrm{Ca}^{2+}$ influx by using a positive $(+30 \mathrm{mV})$ test step to reduce $\mathrm{Ca}^{2+}$ driving force slowed replenishment, (3) photolytic unblocking of $\mathrm{Ca}^{2+}$ channels increased replenishment, and (4) release of caged $\mathrm{Ca}^{2+}$ increased 
replenishment. One mechanism by which an increase in $\mathrm{Ca}^{2+}$ influx might stimulate replenishment is expansion of the readily releasable pool of vesicles. Expansion of the readily releasable pool increases the number of release sites that can be replenished, and this can cause a linear increase in the rate of replenishment. We found that the size of the releasable pool increased by $20 \%$ when test pulse amplitude was increased from $-30 \mathrm{mV}(25 \mathrm{~ms})$ to $-10 \mathrm{mV}$ ( $25 \mathrm{~ms})$. However, this expansion of the releasable pool only accounts for a portion of the $55 \%$ increase in the rate of replenishment stimulated by an increase in pulse amplitude from -30 to $-10 \mathrm{mV}$. The remaining portion reflects more direct actions of $\mathrm{Ca}^{2+}$ on mechanisms of replenishment. Consistent with this, replenishment rates increased with stimuli that enhanced $\mathrm{Ca}^{2+}$ influx but did not expand the readily releasable pool (Fig. 6).

Regulation of replenishment by intracellular $\mathrm{Ca}^{2+}$ levels has been found at other conventional and ribbon synapses (Mennerick and Matthews, 1996; Dittman and Regehr, 1998; Stevens and Wesseling, 1998; Wang and Kaczmarek, 1998; Gomis et al., 1999; Sakaba and Neher, 2001; Kuromi and Kidokoro, 2002, 2005; Singer and Diamond, 2006; Hosoi et al., 2007; Johnson et al., 2008; Sakaba, 2008). At the basket cell synapse in the cerebellum, acceleration of replenishment required high $\mathrm{Ca}^{2+}$ levels matching the high $\mathrm{Ca}^{2+}$ levels needed to stimulate exocytosis (Sakaba, 2008). At other synapses, replenishment is accelerated by much lower levels of $\mathrm{Ca}^{2+}$ than needed for release (Dittman and Regehr, 1998; Stevens and Wesseling, 1998; Wang and Kaczmarek, 1998). At the cone synapse, replenishment and release exhibit a similar $\mathrm{Ca}^{2+} \mathrm{de}-$ pendence to one another, but both are stimulated by very low $\mathrm{Ca}^{2+}$ levels (Rieke and Schwartz, 1996; Thoreson et al., 2004; Sheng et al., 2007). Similar $\mathrm{Ca}^{2+}$ dependencies help these two processes remain in balance with one another. Along with the balance between endocytosis and exocytosis (Rieke and Schwartz, 1996), maintaining a balance between release and replenishment is essential for cones to maintain release for hour upon hour in dim light conditions.

Although release and replenishment at the cone synapse exhibit similar $\mathrm{Ca}^{2+}$ dependencies, effects of $\mathrm{Ca}^{2+}$ buffers indicate that these two processes involve spatially distinct sites. The finding that cone-driven EPSCs were not significantly diminished by the inclusion of $1 \mathrm{~mm}$ BAPTA in the cone patch pipette suggests that sites of vesicle release are close $(<200 \mathrm{~nm})$ to $\mathrm{Ca}^{2+}$ channels. By contrast, replenishment was significantly diminished by elevating EGTA from 0.5 to $5 \mathrm{~mm}$, indicating that this process involves sites $>200 \mathrm{~nm}$ from $\mathrm{Ca}^{2+}$ channels. In cone terminals, the synaptic ribbon, which is believed to tether the reserve pool of vesicles (LoGiudice et al., 2008), extends a few hundred nanometers into the cytoplasm (Sjostrand, 1958; Morgans, 2000). Thus, the effects of different $\mathrm{Ca}^{2+}$ buffers are consistent with the idea that the actions of on replenishment may involve sites along the ribbon.

After the initial test pulse had depleted the readily releasable pool, we often observed a quiescent period of release that persisted for a couple hundred milliseconds. During this quiescent period, subsequent pulses evoked little or no release (Fig. 2, inset). After this time, release recovered slightly, although EPSCs remained quite small throughout the remainder of the pulse train. We observed a similar brief quiescent period before the acceleration of release following elevation of $\mathrm{Ca}^{2+}$ levels by $\mathrm{Ca}^{2+}$ uncaging or photolytic disinhibition of nifedipine (Figs. 7, 9, insets). This brief quiescent period may reflect the $\sim 250 \mathrm{~ms}$ delay exhibited by docked vesicles in bipolar cells before they can fuse
(Zenisek et al., 2000). Thus, $\mathrm{Ca}^{2+}$ may facilitate replenishment by accelerating the rate at which releasable vesicles dock at the base of the ribbon.

The proteins controlling replenishment and release have not been fully elucidated. At the calyx of Held, the primary $\mathrm{Ca}^{2+}$ sensor responsible for accelerating replenishment appears to be calmodulin (Sakaba and Neher, 2001), but the effects also involve calmodulin's interactions with other different proteins. One target of calmodulin is the GTP-binding protein, rab3A (Kim et al., 2002), which plays a role in regulating replenishment (Leenders et al., 2001). This is an appealing candidate for regulating replenishment at the cone synapse, since rab3 A interacts with Rim2 proteins found along the ribbon (Fukuda, 2003; Dulubova et al., 2005; tom Dieck et al., 2005; DeguchiTawarada et al., 2006).

When cones are hyperpolarized in the presence of bright illumination, the readily releasable pool can be fully replenished. The depolarization of cones at light offset evokes a burst of release that is closely synchronized with $\mathrm{Ca}^{2+}$ channel openings (Rabl et al., 2005). With sustained release in continued darkness, the readily releasable pool is soon depleted and release rates become governed by replenishment (Jackman et al., 2009). The occurrence of $\mathrm{Ca}^{2+}$ channel openings in depolarized photoreceptors exhibits a Poisson distribution (Thoreson et al., 2000). If the sustained release of vesicles in darkness were tightly coupled to individual $\mathrm{Ca}^{2+}$ channel openings, the resulting Poisson release probability would impair the detection of small responses by the postsynaptic bipolar cell (Schein and Ahmad, 2006). One potential advantage of having replenishment control the rate of sustained release may be to make release more regular. $\mathrm{Ca}^{2+}$-dependent replenishment involves sites situated a few hundred nanometers from $\mathrm{Ca}^{2+}$ channels, allowing average $\mathrm{Ca}^{2+}$ from multiple channels to control release. This can reduce the noise from stochastic $\mathrm{Ca}^{2+}$ channel openings as well as allowing $\mathrm{Ca}^{2+}$ derived from other sources [e.g., CICR or store-operated channels (Cadetti et al., 2006; Szikra et al., 2008, 2009; Babai et al., 2010)] to regulate sustained release.

While $\mathrm{Ca}^{2+}$-dependent mechanisms of replenishment are common to many synapses, the cone ribbon synapse is unusual in that replenishment plays a more direct role in controlling sustained release rates (Jackman et al., 2009). At the cone ribbon synapse, regulation of replenishment by voltage-dependent changes in $\mathrm{Ca}^{2+}$ influx and pool size is thus not simply a way to maintain release for long periods of time but provides a mechanism for encoding light-evoked changes in membrane potential into changes in sustained release rates.

\section{References}

Adler EM, Augustine GJ, Duffy SN, Charlton MP (1991) Alien intracellular calcium chelators attenuate neurotransmitter release at the squid giant synapse. J Neurosci 11:1496-1507.

Babai N, Morgans CW, Thoreson WB (2010) Calcium-induced calcium release contributes to synaptic release from mouse rod photoreceptors. Neuroscience 165:1447-1456.

Bartoletti TM, Babai N, Thoreson WB (2010) Vesicle pool size at the salamander cone ribbon synapse. J Neurophysiol 103:419-423.

Cadetti L, Tranchina D, Thoreson WB (2005) A comparison of release kinetics and glutamate receptor properties in shaping rod-cone differences in EPSC kinetics in the salamander retina. J Physiol 569:773-788.

Cadetti L, Bryson EJ, Ciccone CA, Rabl K, Thoreson WB (2006) Calciuminduced calcium release in rod photoreceptor terminals boosts synaptic transmission during maintained depolarization. Eur J Neurosci 23:2983-2990.

Cadetti L, Bartoletti TM, Thoreson WB (2008) Quantal mEPSCs and resid- 
ual glutamate: how horizontal cell responses are shaped at the photoreceptor ribbon synapse. Eur J Neurosci 27:2575-2586.

Choi S-Y, Jackman S, Thoreson WB, Kramer RH (2008) Light regulation of $\mathrm{Ca}^{2+}$ in the cone photoreceptor synaptic terminal. Vis Neurosci 25:693-700.

Deguchi-Tawarada M, Inoue E, Takao-Rikitsu E, Inoue M, Kitajima I, Ohtsuka T, Takai Y (2006) Active zone protein CAST is a component of conventional and ribbon synapses in mouse retina. J Comp Neurol 495: $480-496$.

DeVries SH (2001) Exocytosed protons feedback to suppress the $\mathrm{Ca}^{2+}$ current in mammalian cone photoreceptors. Neuron 32:1107-1117.

Dittman JS, Regehr WG (1998) Calcium dependence and recovery kinetics of presynaptic depression at the climbing fiber to Purkinje cell synapse. J Neurosci 18:6147-6162.

Dulubova I, Lou X, Lu J, Huryeva I, Alam A, Schneggenburger R, Südhof TC, Rizo J (2005) A Munc13/RIM/Rab3 tripartite complex: from priming to plasticity? EMBO J 24:2839-2850.

Duncan G, Rabl K, Gemp I, Heidelberger R, Thoreson WB (2010) Quantitative analysis of synaptic release at the photoreceptor synapse. Biophys J 98:2102-2110.

Fukuda M (2003) Distinct rab binding specificity of Rim1, Rim2, rabphilin, and Noc2. identification of a critical determinant of Rab3A/Rab27A recognition by Rim2. J Biol Chem 278:15373-15380.

Gomis A, Burrone J, Lagnado L (1999) Two actions of calcium regulate the supply of releasable vesicles at the ribbon synapse of retinal bipolar cells. J Neurosci 19:6309-6317.

Hirasawa H, Kaneko A (2003) pH changes in the invaginating synaptic cleft mediate feedback from horizontal cells to cone photoreceptors by modulating $\mathrm{Ca}^{2+}$ channels. J Gen Physiol 122:657-671.

Hosoi N, Arai I, Tachibana M (2005) Group III metabotropic glutamate receptors and exocytosed protons inhibit L-type calcium currents in cones but not in rods. J Neurosci 25:4062-4072.

Hosoi N, Sakaba T, Neher E (2007) Quantitative analysis of calciumdependent vesicle recruitment and its functional role at the calyx of held synapse. J Neurosci 27:14286-14298.

Innocenti B, Heidelberger R (2008) Mechanisms contributing to tonic release at the cone photoreceptor ribbon synapse. J Neurophysiol 99:25-36.

Jackman SL, Choi SY, Thoreson WB, Rabl K, Bartoletti TM, Kramer RH (2009) Role of the synaptic ribbon in transmitting the cone light response. Nat Neurosci 12:303-310.

Johnson SL, Forge A, Knipper M, Münkner S, Marcotti W (2008) Tonotopic variation in the calcium dependence of neurotransmitter release and vesicle pool replenishment at mammalian auditory ribbon synapses. J Neurosci 28:7670-7678.

Kaplan JH, Ellis-Davies GC (1988) Photolabile chelators for the rapid photorelease of divalent cations. Proc Natl Acad Sci U S A 85:6571-6575.

Kawai F (1999) Characterization of spontaneous excitatory synaptic currents in newt retinal bipolar cells. Neurosci Lett 271:49-52.

Kim AR, Choi WH, Lee SR, Kim JS, Jeon CY, Kim JI, Kim J, Lee JY, Kim EG, Park JB (2002) Phosphorylation of 46-kDa protein of synaptic vesicle membranes is stimulated by GTP and $\mathrm{Ca}^{2+} /$ calmodulin. Exp Mol Med 34:434-443.

Kuromi H, Kidokoro Y (2002) Selective replenishment of two vesicle pools depends on the source of $\mathrm{Ca}^{2+}$ at the Drosophila synapse. Neuron 35:333-343.

Kuromi H, Kidokoro Y (2005) Exocytosis and endocytosis of synaptic vesicles and functional roles of vesicle pools: lessons from the Drosophila neuromuscular junction. Neuroscientist 11:138-147.

Leenders AG, Lopes da Silva FH, Ghijsen WE, Verhage M (2001) Rab3a is involved in transport of synaptic vesicles to the active zone in mouse brain nerve terminals. Mol Biol Cell 12:3095-3102.

Lev-Ram V, Miyakawa H, Lasser-Ross N, Ross WN (1992) Calcium transients in cerebellar Purkinje neurons evoked by intracellular stimulation. J Neurophysiol 68:1167-1177.

LoGiudice L, Sterling P, Matthews G (2008) Mobility and turnover of vesicles at the synaptic ribbon. J Neurosci 28:3150-3158.

Maple BR, Gao F, Wu SM (1999) Glutamate receptors differ in rod- and cone-dominated off-center bipolar cells. Neuroreport 10:3605-3610.

Mennerick S, Matthews G (1996) Ultrafast exocytosis elicited by calcium current in synaptic terminals of retinal bipolar neurons. Neuron 17:1241-1249.
Morgans CW (2000) Neurotransmitter release at ribbon synapses in the retina. Immunol Cell Biol 78:442-446.

Murata Y, Iwasaki H, Sasaki M, Inaba K, Okamura Y (2005) Phosphoinositide phosphatase activity coupled to an intrinsic voltage sensor. Nature 435:1239-1243.

Nachman-Clewner M, St Jules R, Townes-Anderson E (1999) L-type calcium channels in the photoreceptor ribbon synapse: localization and role in plasticity. J Comp Neurol 415:1-16.

Naraghi M, Müller TH, Neher E (1998) Two-dimensional determination of the cellular $\mathrm{Ca}^{2+}$ binding in bovine chromaffin cells. Biophys $\mathrm{J} 75$ : 1635-1647.

Patneau DK, Vyklicky L Jr, Mayer ML (1993) Hippocampal neurons exhibit cyclothiazide-sensitive rapidly desensitizing responses to kainate. J Neurosci 13:3496-3509.

Rabl K, Cadetti L, Thoreson WB (2005) Kinetics of exocytosis is faster in cones than in rods. J Neurosci 25:4633-4640.

Rabl K, Cadetti L, Thoreson WB (2006) Paired-pulse depression at photoreceptor synapses. J Neurosci 26:2555-2563.

Rieke F, Schwartz EA (1996) Asynchronous transmitter release: control of exocytosis and endocytosis at the salamander rod synapse. J Physiol 493:1-8.

Roberts WM (1993) Spatial calcium buffering in saccular hair cells. Nature $363: 74-76$

Sakaba T (2008) Two Ca(2+)-dependent steps controlling synaptic vesicle fusion and replenishment at the cerebellar basket cell terminal. Neuron $57: 406-419$.

Sakaba T, Neher E (2001) Calmodulin mediates rapid recruitment of fast-releasing synaptic vesicles at a calyx-type synapse. Neuron 32:1119-1131.

Sakaba T, Schneggenburger R, Neher E (2002) Estimation of quantal parameters at the calyx of held synapse. Neurosci Res 44:343-356.

Sanguinetti MC, Kass RS (1984) Voltage-dependent block of calcium channel current in the calf cardiac Purkinje fiber by dihydropyridine calcium channel antagonists. Circ Res 55:336-348.

Schein S, Ahmad KM (2006) Efficiency of synaptic transmission of singlephoton events from rod photoreceptor to rod bipolar dendrite. Biophys J 91:3257-3267.

Schneggenburger R, Meyer AC, Neher E (1999) Released fraction and total size of a pool of immediately available transmitter quanta at a calyx synapse. Neuron 23:399-409.

Schneggenburger R, Sakaba T, Neher E (2002) Vesicle pools and short-term synaptic depression: lessons from a large synapse. Trends Neurosci 25:206-212.

Sheng Z, Choi SY, Dharia A, Li J, Sterling P, Kramer RH (2007) Synaptic $\mathrm{Ca}^{2+}$ in darkness is lower in rods than cones, causing slower tonic release of vesicles. J Neurosci 27:5033-5042.

Singer JH, Diamond JS (2006) Vesicle depletion and synaptic depression at a mammalian ribbon synapse. J Neurophysiol 95:3191-3198.

Sjostrand FS (1958) Ultrastructure of retinal rod synapses of the guinea pig eye as revealed by three-dimensional reconstructions from serial sections. J Ultrastruct Res 2:122-170.

Steele EC Jr, Chen X, Iuvone PM, MacLeish PR (2005) Imaging of $\mathrm{Ca}^{2+}$ dynamics within the presynaptic terminals of salamander rod photoreceptors. J Neurophysiol 94:4544-4553.

Stevens CF, Wesseling JF (1998) Activity-dependent modulation of the rate at which synaptic vesicles become available to undergo exocytosis. Neuron 21:415-424.

Szikra T, Krizaj D (2006) The dynamic range and domain-specific signals of intracellular calcium in photoreceptors. Neuroscience 141:143-155.

Szikra T, Cusato K, Thoreson WB, Barabas P, Bartoletti TM, Krizaj D (2008) Depletion of calcium stores regulates calcium influx and signal transmission in rod photoreceptors. J Physiol 586:4859-4875.

Szikra T, Barabas P, Bartoletti TM, Huang W, Akopian A, Thoreson WB, Krizaj D (2009) Calcium homeostasis and cone signaling are regulated by interactions between calcium stores and plasma membrane ion channels. PLoS One 4:e6723.

Thoreson WB, Nitzan R, Miller RF (1997) Reducing extracellular $\mathrm{Cl}^{-}$suppresses dihydropyridine-sensitive $\mathrm{Ca}^{2+}$ currents and synaptic transmission in amphibian photoreceptors. J Neurophysiol 77:2175-2190.

Thoreson WB, Nitzan R, Miller RF (2000) Chloride efflux inhibits single calcium channel open probability in vertebrate photoreceptors: chloride 
imaging and cell-attached patch-clamp recordings. Vis Neurosci 17: 197-206.

Thoreson WB, Rabl K, Townes-Anderson E, Heidelberger R (2004) A highly $\mathrm{Ca}^{2+}$-sensitive pool of vesicles contributes to linearity at the rod photoreceptor ribbon synapse. Neuron 42:595-605.

tom Dieck S, Altrock WD, Kessels MM, Qualmann B, Regus H, Brauner D, Fejtová A, Bracko O, Gundelfinger ED, Brandstätter JH (2005) Molecular dissection of the photoreceptor ribbon synapse: physical interaction of bassoon and RIBEYE is essential for the assembly of the ribbon complex. J Cell Biol 168:825-836.

Tsien RY (1980) New calcium indicators and buffers with high selectivity against magnesium and protons: design, synthesis, and properties of prototype structures. Biochemistry 19:2396-2404.
Wang LY, Kaczmarek LK (1998) High-frequency firing helps replenish the readily releasable pool of synaptic vesicles. Nature 394:384-388.

Wilkinson MF, Barnes S (1996) The dihydropyridine-sensitive calcium channel subtype in cone photoreceptors. J Gen Physiol 107:621630.

Xu JW, Slaughter MM (2005) Large-conductance calcium-activated potassium channels facilitate transmitter release in salamander rod synapse. J Neurosci 25:7660-7668.

Yamada KA, Tang CM (1993) Benzothiadiazides inhibit rapid glutamate receptor desensitization and enhance glutamatergic synaptic currents. J Neurosci 13:3904-3915.

Zenisek D, Steyer JA, Almers W (2000) Transport, capture and exocytosis of single synaptic vesicles at active zones. Nature 406:849-854. 